\title{
Subtribo Oncidiinae Benth. (Orchidaceae Juss.) no Distrito Federal, Brasil ${ }^{1}$
}

\author{
Viviane Vaz de Queiroz ${ }^{2,4}$, Carolyn Elinore Barnes Proença ${ }^{2}$ e Luciano de Bem Bianchetti ${ }^{3}$
}

Recebido: 20.04.2015; aceito: 17.09.2015

\begin{abstract}
Subtribe Oncidiinae Benth. (Orchidaceae Juss.) in Distrito Federal, Brazil). Oncidiinae is the second largest subtribe of the orchids in the Americas. According to the Brazilian database Lista de Espécies da Flora do Brasil, the representativity of the subtribe in Distrito Federal is of 15 genera and 19 species. The objective of this study was to develop a taxonomic treatment of the subtribe for the Flora of Distrito Federal, Brazil. Field trips, consultations to the herbaria BHCB, CEN, HEPH, IBGE, and UB and morphological analysis of all the material were made. A new occurrence of species and genus, Trichopilia brasiliensis Cong., was registered to Distrito Federal After this study, the taxa list for Oncidiinae of Distrito Federal should be corrected to 15 genera and 18 species. Descriptions, identification keys, and illustrations for taxa were prepared. We concluded that some species of Oncidiinae occurring in Distrito Federal have wide distribution while others are locally rare and require intense effort of collection for registration.
\end{abstract}

Keywords: Brasília, floristics, morphology, orchids, taxonomy

RESUMO - (Subtribo Oncidiinae Benth. (Orchidaceae Juss.) no Distrito Federal, Brasil). Oncidiinae é a segunda maior subtribo de orquídeas das Américas. Segundo a Lista de Espécies da Flora do Brasil, a representatividade da subtribo no Distrito Federal é de 15 gêneros e 19 espécies. O objetivo deste trabalho foi elaborar um tratamento taxonômico da subtribo para a Flora do Distrito Federal, Brasil. Foram feitas saídas de campo, consultas aos herbários BHCB, CEN, HEPH, IBGE, e UB, e análise morfológica de todo o material. Foi registrado mais um gênero e uma espécie para o Distrito Federal, Trichopilia brasiliensis Cong. Depois deste estudo, a referida lista de táxons de Oncidiinae para o Distrito Federal deverá ser corrigida para 15 gêneros e 18 espécies. Foram elaboradas descrições, chaves de identificação e ilustrações para os táxons. Conclui-se que algumas espécies de Oncidiinae ocorrentes no Distrito Federal possuem ampla distribuição enquanto que outras se mostram localmente raras e exigem intenso esforço de coleta para seu registro.

Palavras-chave: Brasília, florística, morfologia, orquídeas, taxonomia

\section{Introdução}

As orquídeas são monocotiledôneas e pertencem a uma das maiores e mais diversificadas famílias de plantas com flores do mundo (Dressler 1981). A estimativa é que existam, no mundo, cerca de 25.400 espécies, subordinadas em cerca de 1.000 gêneros (Baptista et al. 2011). Apresenta uma presença marcante nas Américas, sendo a Colômbia o país com maior número de espécies, 4.010, seguido pelo Equador com 3.784 espécies e pelo Brasil com 2.459 espécies (Dodson 2003, Sarmiento 2007, Barros et al. 2015).
A subfamília Epidendroideae Lindl., possui cerca de 600 gêneros e 18.000 espécies, e é dividida em 14 tribos, sendo uma delas a tribo Cymbidieae Pfitzer (Pridgeon et al. 2005). Epidendroideae é caracterizada por apresentar antera terminal, 2-8 polínias rígidas, com consistência cartilaginosa, geralmente com apêndices como caudículo, estipe e viscídio; o ginostêmio pode prolongar-se formando um pé da coluna, tendo a base das sépalas laterais adnatas a ele formando um mento (Pridgeon et al. 2005, Baptista et al. 2011).

A tribo Cymbidieae apresenta distribuição em todos os continentes, predominantemente

1. Parte da Dissertação de Mestrado do primeiro Autor

2. Universidade de Brasília (UnB), Departamento de Botânica, Instituto de Biologia, Bloco D, 1ª Andar, 70919-900, Brasília, DF, Brasil

3. Empresa Brasileira de Pesquisa Agropecuária, Recursos Genéticos e Biotecnologia, Brasília, Parque Estação Biológica, Av. W5 Norte (final), 70770-901, Brasília, DF, Brasil

4. Autor para correspondência: vivi.vqueiroz@gmail.com 
na América tropical e morfologicamente é caracterizada por apresentar plantas com crescimento predominantemente simpodial, raramente terrestres, geralmente com pseudobulbos, folhas plicadas ou conduplicadas, articuladas, inflorescências basais, sépalas laterais às vezes fundidas, pétalas livres, labelo geralmente trilobado, calosidade (quando presente) de várias formas (quilha, corniculado, carenado, piloso), coluna algumas vezes alada, com aurículas ou estelídeos, polinário com 2-4 polínias, com estipe e viscídio (Cribb 2009). Compreende 11 subtribos, incluindo Oncidiinae Benth., objeto do presente estudo.

A subtribo Oncidiinae é uma das mais diversas subtribos de Orchidaceae e a segunda maior subtribo das Américas com uma expressiva diversidade na morfologia floral e vegetativa, comportando 69 gêneros e cerca de 1.700 espécies de distribuição exclusivamente neotropical (Chase 2009, Penha et al. 2011). No Brasil, a representatividade da subtribo é de 49 gêneros e cerca de 360 espécies, sendo que no Distrito Federal encontram-se 15 gêneros e 19 espécies (Barros et al. 2015).

Estudos filogenéticos vêm demonstrando que muitos gêneros de Oncidiinae, em sua circunscrição tradicional, são polifiléticos ou parafiléticos (Williams et al. 2001). Dentro de uma visão moderna, visando estabelecer a monofilia dos gêneros, é necessária uma ampliação na circunscrição de alguns gêneros, juntamente com as alterações nomenclaturais necessárias (Williams et al. 2001).

Uma das novas propostas filogenéticas (Chase et al. 2009) para os gêneros de Oncidiinae, na tentativa de realizar arranjos monofiléticos, sugeriu que espécies pertencentes a gêneros anteriormente autônomos como Alatiglossum D.H. Baptista, Baptistonia Barb. Rodr., Binotia Rolfe, Carriella V.P. Castro \& K.G. Lacerda, Coppensia Dumort., Ornithophora Barb. Rodr., Rodrigueziella Kuntze e Rodrigueziopsis Schltr., entre outros, sejam transferidos para Gomesa R. Br. s.l. Do mesmo modo, o trabalho de Williams et al. (2001), corroborado por Chase (2009), também sugeriu novos arranjos, transferindo espécies pertencentes a gêneros como Cohniella Pfitzer, Lophiarella Szlach., Lophiaris Raf., entre outros, para Trichocentrum Poepp. \& Endl. s.l. Aqui deve-se considerar que muitos autores (Sandoval-Zapotitla \& Terrazas 2001, Sosa et al. 2001, Chase 2009, WCSP 2014, entre outros) aceitam as propostas realizadas por Williams et al. (2001) e Chase et al. (2009).
Por outro lado, e discordando dos novos arranjos propostos acima, Braem (1993), Pupulin (1995), Königer \& Pongratz (1997, 1999), Jiménez-Machorro \& Carnevali (2001), Pupulin \& Carnevali (2005) e Carnevali et al. (2013), além dos autores responsáveis pela elaboração da Lista das Espécies da Flora do Brasil (2015), reconheceram gêneros menores (Alatiglossum, Coppensia, Cohniella, Lophiaris e Trichocentrum s.s., entre outros), desde que possuam suporte monofilético, justificando a facilidade no reconhecimento de caracteres morfológicos e anatômicos e a facilidade em diagnosticar gêneros com uma delimitação mais estreita.

Embora as duas abordagens sejam importantes e tratem do conhecimento da evolução dos gêneros e da circunscrição dos mesmos, é recomendável que, em estudos que tratem de diversidade ou riqueza para o Distrito Federal, seja explicitada qual abordagem foi utilizada, pois os resultados serão fortemente influenciados devido à grande variação no número de gêneros.

A flora do Distrito Federal registra entre 148 famílias e 3.188 espécies de fanerógamas (Proença et al. 2001) e 154 famílias e 3.131 espécies (Lista de Espécies da Flora do Brasil 2015) e, especificamente quanto à família Orchidaceae a bibliografia registra entre 72 gêneros e 246 espécies (Batista \& Bianchetti 2003) e 77 gêneros e 236 espécies (Barros et al. 2015).

No Distrito Federal, foram realizados trabalhos florísticos e morfológicos que geraram listas para Orchidaceae de determinadas fitofisionomias do cerrado (Walter \& Sampaio 1998), para o Distrito Federal como um todo (Proença et al. 2001, Batista \& Bianchetti 2003), para alguns gêneros de ocorrência no Distrito Federal (Pellizzaro et al. 2004, Meneguzzo et al. 2012), ou por Unidades de Conservação (Pereira et al. 1993, Maury et al. 1994, Nogueira et al. 2002, Batista et al. 2005, Bianchetti et al. 2005).

O presente estudo teve como objetivo ampliar o levantamento da subtribo Oncidiinae no Distrito Federal, refinar o conhecimento sobre a localização, os habitats de ocorrência e, fornecer ferramentas (chave e descrição das espécies) que permitam a identificação das espécies, como parte do Projeto Flora do Distrito Federal (Cavalcanti \& Ramos 2001).

\section{Material e métodos}

O Distrito Federal está localizado entre os paralelos $15^{\circ} 30^{\prime}$ e $16^{\circ} 03^{\prime} \mathrm{S}$ e os meridianos $47^{\circ} 25^{\prime}$ e $48^{\circ} 12^{\prime} \mathrm{W}$, no planalto central do Brasil. Ocupa área 
de $5.783 \mathrm{~km}^{2}$ e apresenta altitude média de $1.100 \mathrm{~m}$. O clima caracteriza-se por apresentar os tipos tropical com uma estação seca, Aw e tropical de altitude, Cwa e Cwb marcados por duas estações bem definidas: a) uma estação chuvosa, que vai de outubro a abril, apresentando maior pluviosidade entre dezembro e fevereiro que oscila entre 1.200 e $1.750 \mathrm{~mm}$; b) uma estação seca, que se estende de maio a setembro, com a umidade relativa do ar variando de $70 \%$ a menos de 20\% no final da estação (Codeplan 1984).

Trabalhos atuais, como o de Françoso et al. 2015, apontam que o Cerrado brasileiro, a maior e mais rica savana Neotropical, vem sofrendo drástico antropismo aliado, especialmente, à atividades agropecuárias, produção de carvão, hidroelétricas e expansão de áreas urbanas. Dados mais conservadores (Françoso et al. 2015) registram que $50 \%$ da cobertura original daquele bioma já foi alterado. Outros (Sloan et al. 2014) registram que o bioma Cerrado possui apenas $19,8 \%$ de vegetação natural intacta.

De acordo com as referências, pelo menos 50\% da vegetação original do bioma Cerrado foi alterada ou suprimida tanto no passado quanto nos dias atuais sem que as causas dessa redução possam ter cessado. Desse modo, mesmo partindo-se do pressuposto que as populações (ou subpopulações) não estivessem uniformemente distribuídas no bioma, estima-se ter havido, indiscriminadamente, uma diminuição proporcional no tamanho populacional (critério A) para todas as espécies que habitam o bioma. Portanto, todas as espécies passam a ser classificadas, no mínimo, como ameaçadas na categoria Vulnerável. Classificação = VU A2 c.

Quanto à vegetação, estão presentes, no DF, praticamente todas as fitofisionomias já descritas para o bioma cerrado, o que lhe permite apresentar uma rica diversidade vegetal. De acordo com a terminologia proposta por Ribeiro \& Walter (1998), encontram-se no Distrito Federal formações florestais (matas de galeria, ciliares, seca e cerradão), formações savânicas, principalmente o cerrado sentido restrito com seus quatro subtipos (denso, típico, ralo e rupestre), veredas e palmeirais, até formações campestres (campos sujo, limpo e rupestre).

Quanto à abordagem taxonômica concordamos com os autores Braem (1993), Pupulin (1995), Königer \& Pongratz (1997, 1999), JiménezMachorro \& Carnevali (2001), Pupulin \& Carnevali (2005), e Carnevali et al. (2013), reconhecendo Alatiglossum e Coppensia, ao invés de Gomesa (s.l.), e Cohniella, Lophiaris e Trichocentrum s.s. ao invés de Trichocentrum s.l.
Foi realizado um levantamento nos herbários de Brasília e no INCT (2014). No levantamento foram registrados dados das etiquetas, locais de coleta, coletores, datas e informações pertinentes. Foram consultados e analisados materiais depositados nos seguintes herbários: Empresa Brasileira de Agricultura e Pecuária - Recursos Genéticos e Biotecnologia (CEN); Jardim Botânico de Brasília - Herbário Ezechias Paulo Heringer (HEPH); Reserva Ecológica do Instituto Brasileiro de Geografia e Estatística (IBGE); e Universidade de Brasília (UB); acrônimos de acordo com Thiers (2015).

Foram realizadas nove saídas de coletas ao campo (uma coleta em 10/2013; uma coleta em 11/2013; duas coletas em 06/2014; duas coletas em 10/2014; duas coletas em 11/2014; uma coleta em 12/2014). Os materiais que comportavam estruturas reprodutivas foram desidratados e incorporados no Herbário UB, com duplicatas no Herbário CEN. Os materiais que não comportavam estruturas reprodutivas foram coletados para cultivo no viveiro Empresa Brasileira de Agricultura e Pecuária - Recursos Genéticos e Biotecnologia (CEN) até apresentar florescimento e posterior identificação.

Para descrição dos gêneros foi utilizada bibliografia especializada onde constavam as características diagnósticas para cada gênero (Garay \& Stacy 1974, Braem 1993, CRIA 2005, Chase 2009). As descrições genéricas abrangem principalmente a variabilidade morfológica total do gênero (exceto para Ionopsis Kunth, pois pelo menos uma espécie do gênero, Ionopsis satyrioides (Sw.) Lindl., que ocorre na América Central e região norte da América do Sul, incluindo a região norte do Brasil, apresenta folhas levemente teretes. A inclusão dessa característica eventual na descrição do gênero (Ionopsis) descartaria a utilização, na chave, dessa mesma característica marcante (folhas teretes) para o gênero Cohniella) e não se detém às características apresentadas exclusivamente pelas espécies de ocorrência no Distrito Federal. A maior parte dos frutos não foi vista e as descrições foram retiradas de bibliografia pertinente (CRIA 2005, Chase 2009). Foi confeccionada uma chave para os gêneros de Oncidiinae de ocorrência no Distrito Federal e elaborados comentários quanto à etimologia, distribuição geral, distribuição no bioma Cerrado e no Distrito Federal. Dados sobre distribuição geográfica dos gêneros e espécies foram retirados de trabalhos específicos e especialmente da compilação de dados disponíveis em sites (Tropicos 2014, WCSP 2014, 
Barros et al. 2015). Foram confeccionadas 55 fichas de diagnose floral (visando à compreensão e medição das peças) incluindo todos os indivíduos examinados que ainda não tivessem as referidas fichas anexadas aos vouchers. Para a confecção das fichas foi retirada uma flor de cada exsicata que, depois de reidratadas, foram montadas em cartolina e anexadas aos respectivos vouchers. Quando possível foi realizado desenho do labelo, valorizando a região do disco (calos) e a coluna, para melhor compreensão dessas estruturas e morfologia. A identificação tanto do material coletado como do material não identificado já depositado em herbários, foi realizada com base nas obras de Garay \& Stacy (1974), Silva (1999), Pellizzaro et al. (2004), Chase et al. (2009), e Baptista et al. (2011), bem como por comparação com material identificado por especialistas na família.

\section{Resultados e Discussão}

A Subtribo Oncidiinae está bem representada no Distrito Federal, ocorrendo em vários ambientes protegidos, como reservas e unidades de conservação, além de ambientes não protegidos por legislação ambiental. A partir de resultados gerados pelo presente estudo, a Lista de Espécies da Flora do Brasil - Distrito Federal (Barros et al. 2015) deverá ser atualizada da seguinte forma: acréscimo de mais um gênero e duas espécies, Trichopilia brasiliensis Cogn. e Cohniella jonesiana (Rchb. f.) Christenson. A inclusão de $C$. jonesiana, mesmo sem apresentar voucher para o DF, é justificada devido ao fato de ter sido citada por trabalhos anteriores (Pellizzaro et al. 2004, Bianchetti et al. 2005) e por apresentar registros em localidades próximas ao Distrito Federal, como Unaí - MG, por exemplo. A supressão de Coppensia bifolia (Sims) Dumort. e de Notylia hemitricha Barb. Rodr. é em decorrência de amostras erroneamente identificadas. A supressão da ocorrência de Rodriguezia brachystachys Rchb. f. \& Warm. e de
Gomesa foliosa (Hook.) Klotzsch \& Rchb. f. é devido ao fato de não apresentarem vouchers e nem registros para proximidades do Distrito Federal. Desse modo, a representação da subtribo Oncidiinae, para a Flora do Distrito Federal, deverá ser atualizada para 15 gêneros e 18 espécies.

Subtribo Oncidiinae Benth., J. Linn. Soc., Bot. 18: 288. 1881.

Ervas geralmente epífitas, menos frequentemente terrícolas, crescimento simpodial. Pseudobulbos heteroblásticos, base geralmente protegida por bainhas desenvolvidas com ou sem limbos, encimados por 1-3 folhas. Folhas dísticas, apicais, geralmente conduplicadas, bilaterais a unilaterais, às vezes cilíndricas ou terete ou lateralmente achatadas, geralmente articuladas. Inflorescência geralmente lateral (raramente terminal), simples a ramificada, 1 a multiflora, geralmente protegida por bainha. Flores geralmente ressupinadas, diminutas a grandes (no máximo $10 \mathrm{~cm}$ de diâmetro). Sépalas geralmente livres, em alguns casos sépalas laterais sinsépalas e, ocasionalmente formando esporão. Pétalas geralmente livres, raramente adnatas a base da coluna. Labelo geralmente livre, geralmente sem nectário, algumas vezes com esporão nectarífico, calo muitas vezes produzindo óleo, com morfologia complexa. Coluna ereta, geralmente alongada, muitas vezes com asas ou outros apêndices, às vezes na base apresentando tecido semelhante ao calo do labelo (tábula infraestigmática), raramente com base projetada formando um pé da coluna; clinândrio geralmente liso, em alguns casos muito desenvolvido, lacerado; antera terminal, operculada; polinário formado por 2-4 polínias, compactas e rígidas, viscídio presente; estigma ventral, inteiro ou bilobado, geralmente próximo ao ápice da coluna; rostelo frequentemente afilado, às vezes alongado. Ovário glabro, raramente equinado. Cápsula 3-(6) rimosa.

Chave para os gêneros de Oncidiinae ocorrentes no Distrito Federal

1. Folhas equitantes, imbricadas ou flabeliformes

2. Folhas não articuladas, obliquamente triangulares 7. Lockhartia

2. Folhas articuladas, ensiformes ou flabeliformes

3. Inflorescência uniflora; flores calcaradas . 11. Plectrophora

3. Inflorescência multiflora; flores ecalcaradas 9. Macroclinium

1. Folhas com morfologia diversa

4. Folhas conduplicadas, teretes 3. Cohniella

4. Folhas conduplicadas de outras maneiras

5. Folhas carnosas, geralmente pintalgadas de roxo 
6. Flores calcaradas; coluna não alada, com braços apicais desenvolvidos 14. Trichocentrum

6. Flores ecalcaradas; coluna alada, sem braços apicais 8. Lophiaris

5. Folhas coriáceas, sem pintas

7. Labelo inserido na metade da coluna

2. Aspasia

7. Labelo inserido na base da coluna

8. Sépalas laterais completamente fundidas formando esporão

4.Comparettia

8. Sépalas laterais livres ou parcialmente fundidas, sem esporão ou formando pequeno mento

9. Clinândrio muito desenvolvido (acima da antera), lacerado .... 15. Trichopilia

9. Clinândrio pouco ou não desenvolvido, liso ou inteiro

10. Coluna com asas ou estelídios desenvolvidos ladeando o estigma; presença de tábula infraestigmática

11. Pétalas mais largas e mais longas que as sépalas

1. Alatiglossum

11. Pétalas de tamanho similar às sépalas

5. Coppensia

10. Coluna sem asas ou estelídios; ausência de tábula infraestigmática

12. Labelo obovado, oblanceolado, oblongo, ou oval, ápice geralmente emarginado

13. Labelo obovado, oblanceolado; ápice muito dilatado em relação à base, emarginado

13. Labelo oblongo a pandurado; ápice não dilatado em relação à base, não emarginado

13. Sanderella

12. Labelo hastado, ápice agudo, não emarginado 10. Notylia

14. Inflorescência tipo panícula; pseudobulbos inconspícuos 6. Ionopsis

14. Inflorescência tipo racemo; pseudobulbos conspícuos 12. Rodriguezia

Alatiglossum Baptista, Colet. Orquídeas Bras. 3: 87. 2006.

Ervas epífitas. Rizoma curto entre os caules secundários. Caules secundários intumescidos em pseudobulbos, fusiformes a ovais, às vezes tetragonais, geralmente sulcados e ancipitados, parcialmente recobertos por bainhas foliares, encimados por 1-2 folhas. Folhas conduplicadas, bifaciais, coriáceas, articuladas, verdes. Inflorescência lateral, tipo racemo ou panícula, comprimento maior que as folhas, multiflora. Flores ressupinadas, explanadas e vistosas, geralmente amarelas e, ocasionalmente, com marcas castanhas ou vermelhas. Sépala dorsal livre; sépalas laterais parcialmente fundidas. Pétalas livres, geralmente maiores, mais largas e de coloração diferente das sépalas. Labelo trilobado, ecalcarado, base do labelo inserido perpendicularmente na base da coluna, lobos laterais auriculados; região do disco com calo bastante verrucoso; margens do disco e istmo geralmente denteadas ou fimbriadas. Coluna com asas semicirculares ou estelídios ladeando o estigma; proeminente tábula infraestigmática presente na base, geralmente composta por duas lamelas, ocasionalmente um sulco; clinândrio pouco desenvolvido, liso. Fruto cápsula cilíndrico-fusiforme, não a levemente 3-angulada; frutos maduros com ápice dos carpelos unidos. O gênero Alatiglossum possui cerca de 16 espécies, distribuídas na Argentina, Bolívia e no Brasil (Docha Neto 2006). No Brasil, ocorrem 14 espécies (11 endêmicas) nos biomas Amazônia, Mata Atlântica, Cerrado e em regiões semiáridas do Nordeste. No bioma Cerrado, ocorrem cinco espécies e duas dessas ocorrem no Distrito Federal (Alatiglossum fuscopetalum (Hoehne) Baptista e Alatiglossum macropetalum (Lindl.) Baptista) (Barros et al. 2015).

\section{Chave para as espécies de Alatiglossum do Distrito Federal}

1. Pétalas similares às sépalas, ápice obtuso, amarelas e densamente pintagaldas a totalmente castanhas .................. 1. A. fuscopetalum

1. Pétalas maiores que as sépalas, ápice emarginado, totalmente amarelas ou pintalgadas de castanho apenas na base

2. A. macropetalum

Alatiglossum fuscopetalum (Hoehne) Baptista, Colet. Orquídeas Brasil. 3: 88. 2006.

Pseudobulbos 2-5 × 0,7-1,8 cm, amareloesverdeados, bainhas $6,8-7,5 \mathrm{~cm}$ comp., persistentes, articuladas, encimados por uma folha. Folha 7-17,7 ×0,7-1,6 cm, séssil, elíptica, base atenuada, ápice agudo. Inflorescência 30-64 cm compr., paniculada, 4-11 flores. Flores pediceladas, pedicelos $0,8-2,1 \mathrm{~cm}$ compr. Sépalas similares, membranáceas, castanhoamareladas, densamente pintalgadas de castanho- 
escuro, base atenuada, margem sinuada, ápice obtuso a acuminado; sépala dorsal $0,6-0,9 \times 0,2-0,5 \mathrm{~cm}$, obovada; sépalas laterais $0,8-1,3 \times 0,2-0,4 \mathrm{~cm}, 1 / 3$ adnatas, elípticas. Pétalas $0,8-1,1 \times 0,6-0,8 \mathrm{~cm}$, obovadas a largamente elípticas, membranáceas, densa a totalmente pintalgadas de castanho-escuro, base levemente angustada, margem pouco sinuada, ápice obtuso, mucronado. Labelo 1,4-1,8 $\times$ 1,2-1,8 cm, amarelo com a região central da calosidade pontilhada de castanho-claro; lobos laterais 2-4 $\times 4-5 \mathrm{~mm}$, elípticos a ovais, amarelos; lobo mediano $0,8-1,1 \times 1,2-1,8 \mathrm{~cm}$, oval, margem levemente erosa, emarginado; istmo ca. $4 \mathrm{~mm}$ compr., amarelo; região do disco com calo complexo, parte basal formada por placa com protuberâncias verrucosas fundidas, parte mediana formado por lamela bífida, parte inferior da lamela com protuberâncias laterais. Coluna 2-3 $\times$ ca. $1 \mathrm{~mm}$, castanha, tábula infraestigmática ca. $1 \times 1 \mathrm{~mm}$, asas ou estelídios ca. $2 \times 1 \mathrm{~mm}$, amarelos. Fruto não visto. A espécie Alatiglossum fuscopetalum ocorre na Bolívia, Paraguai e Brasil (Tropicos 2014, WCSP 2014). No Brasil, distribui-se no Distrito Federal e nos Estados de Goiás, Maranhão, Mato Grosso, Pará e Tocantins (Barros et al. 2015). No Distrito Federal, vegeta em matas mesofíticas (Floresta Estacional Decidual) com afloramento calcário e floresce nos meses de julho e agosto.

Material selecionado: BRASIL. Distrito Federal: APA de Cafuringa, 21-VIII-2002, Z.J.G. Miranda 82 (UB). FERCAL, 6,7 km da fábrica de cimento CIPLAN, 26-VII-1990, L. Bianchetti 869-B (CEN).

Material adicional examinado: BRASIL. GoIÁs: Niquelândia, Futuro reservatório do AHE Serra da Mesa, 8-VII-1997, B.M.T. Walter 3774 (CEN).

Status de Conservação - Considerando apenas dois registros de herbário; considerando o fato de vegetar apenas em Matas Mesofíticas sobre afloramento calcário (sujeitas a diversas situações de ameaça, como por exemplo: extração mineral, incêndios freqüentes, extração de madeira, desmatamentos para agricultura, remanescentes florestais fragmentados e expansão de área urbana) e por não haver registros em Áreas Protegidas de Preservação Integral ou apenas em Áreas Protegidas de Uso Sustentável (APA), no Distrito Federal, a espécie pode ser considerada como localmente em perigo - EN B2ab (ii, iii).

Alatiglossum macropetalum (Lindl.) Baptista, Colet. Orquídeas Brasil. 3: 88. 2006.

Pseudobulbos 1,5-4,5 × 0,7-2,1 cm, amareloesverdeados, bainhas $2-9,7 \mathrm{~cm}$ compr., persistentes, articuladas, encimados por uma folha. Folha 2,2-17,5 × 0,5-1,8 cm, séssil, elíptica, base atenuada, ápice agudo. Inflorescência 27-76,7 cm compr., paniculada, 8-50 flores. Flores pediceladas, pedicelos 1-1,9 cm compr. Sépalas similares, membranáceas, amarelas, densamente pintalgadas de castanho, bases atenuadas, margens levemente sinuadas, ápices agudos; sépala dorsal 6-7 × 2-3 mm, obovada; sépalas laterais $8-9 \times 2-3 \mathrm{~mm},(1 / 3)$ adnatas, elípticas. Pétalas 1-1,4 × 1-1,2 cm, obovadas, membranáceas, totalmente amarelas ou pintalgadas de castanho apenas na base, base breve angustada, margens inteiras, ápice emarginado. Labelo 1,2-1,6 × 1,2-1,6 cm, amarelo com região central da calosidade com manchas castanho-claras; lobos laterais 2-4 × 2-5 mm, elípticos a ovais, amarelos; lobo mediano $0,7-0,9 \times 1,2-1,6 \mathrm{~cm}$, ovado, margem levemente erosa, retuso a emarginado, amarelo; istmo 0,3-1,6 cm; região do disco com calo complexo envolvendo diversas protuberâncias verrucosas e lamelas. Coluna ca. 3,0 × 1,0-2,0 mm, acastanhada, tábula infraestigmática 1-2 $\times 1-2 \mathrm{~mm}$, asas ou estelídios ca. $1 \times 1 \mathrm{~mm}$, amarelos. Fruto não visto.

A espécie Alatiglossum macropetalum ocorre na Bolívia e Brasil (Tropicos 2014). No Brasil, distribui-se no Distrito Federal e nos Estados de Goiás, Maranhão, Mato Grosso, Mato Grosso do Sul, Minas Gerais, Pará, São Paulo e Tocantins (Barros et al. 2015). No Distrito Federal, vegeta em mata ciliar e em Floresta Estacional Semidecidual, com floração nos meses de julho e agosto.

Material selecionado: BRASIL. Distrito Federal: APA de Cafuringa, próximo a comunidade do Córrego do Ouro, VIII-2003, K.F. Pellizzaro et al. 27 (CEN). FERCAL, 6,7 km da fábrica de cimento CIPLAN, 26-VII-1990, L. Bianchetti 869 (CEN). Lajinha, Estrada de Sobradinho, 1-VII-1965, D. Sucre 647 (UB).

Status de Conservação - Considerando apenas cinco registros de herbário; considerando o fato de vegetar apenas em Matas Mesofíticas sobre afloramento calcário (sujeitas a diversas situações de ameaça, como por exemplo: extração mineral, incêndios freqüentes, extração de madeira, desmatamentos para agricultura, remanescentes florestais fragmentados e expansão de área urbana) e por não haver registros em Áreas Protegidas de Preservação Integral ou apenas em Áreas Protegidas de Uso Sustentável (APA), no Distrito Federal, a espécie pode ser considerada como localmente em perigo - EN B2ab (ii, iii). 
Aspasia Lindl., Gen. Spec. Orch. Pl. 139 (1832).

Ervas epífitas. Rizoma curto entre os caules secundários. Caules secundários intumescidos em pseudobulbos, ovais, ancipitados, parcialmente recobertos por brácteas, encimados por 1-2 folhas. Folhas conduplicadas, bifaciais, coriáceas, articuladas, verdes. Inflorescência lateral, tipo racemo, mais curta que o comprimento das folhas, 1-6 flores. Flores ressupinadas, vistosas, cor creme com manchas rosa ou castanhas mais escuras. Sépalas e pétalas livres e similares na forma e tamanho. Labelo trilobado, panduriforme, ecalcarado, inserido na parte mediana da coluna, formando uma cavidade (pseudonectário); lóbulos laterais tão amplos quanto o mediano; região do disco com calo composto por duas nervuras paralelas engrossadas. Coluna não alada, reta; tábula infraestigmática ausente; clinândrio pouco desenvolvido, liso. Fruto cápsula elíptica a ovóide, não a levemente 3-angulada; frutos maduros com ápice dos carpelos unidos.

O gênero Aspasia possui sete espécies que se distribuem na Guatemala, Belize, Panamá, Venezuela, Colômbia, Paraguai, Equador, Peru e Brasil (Chase 2009). No Brasil, ocorrem cinco espécies nos biomas Amazônia, Cerrado e Mata Atlântica. No bioma Cerrado está representado por apenas uma espécie, Aspasia variegata Lindl., que está presente no Distrito Federal (Barros et al. 2015).

Aspasia variegata Lindl., Edwards's Bot. Reg. 22: t. 1907. 1836.

Figura $1 \mathrm{~g}-\mathrm{h}$

Pseudobulbos 3,3-7,7 × 1,4-1,8 cm, verde claros, protegidos por 2-3 bainhas 11,5-19,1 cm compr., persistentes, articuladas. Folhas 10,2-24 × 1,3-3,5 cm, sésseis, estreitamente elípticas a oblanceoladas, base atenuada, ápice agudo. Inflorescência 5,0-9,5 cm comp., 2-4 flores. Flores pediceladas, pedicelos 0,7-1,1 cm comp. Sépalas 1,9-2 × 0,4-0,7 cm, similares, membranáceas, amarelas com listras violáceas, elípticas-obovadas, base atenuadas, margens inteiras, ápice agudo-apiculados. Pétalas 1,7-2 × 0,7-0,8 cm, membranáceas, amarelas com listras violáceas, mais obovadas que as sépalas, base atenuadas, margens inteiras, ápice agudos. Labelo 1,5-1,6 × 1,8-2 cm, amarelo com listras violáceas; lobos laterais 0,5-0,6 comp.; 0,9-1 cm, ovalados, amarelos com listras violáceas; lobo mediano 0,9-1 × 1,2-1,6 cm, oval-subquadrangular, margem sinuada, ápice emarginado; região do disco bicaloso, calos lineares. Coluna 1,4-1,6 cm, castanha. Fruto não visto.
A espécie Aspasia variegata ocorre na Bolívia, Colômbia, Guiana Francesa, Suriname, Trinidade, Venezuela e Brasil (Williams 1974). No Brasil, distribui-se no Distrito Federal e nos Estados do Amapá, Amazonas, Goiás, Maranhão, Mato Grosso, Pará, Rondônia, Roraima e Tocantins (Barros et al. 2015). No Distrito Federal vegeta em mata mesofítica com floração no mês de outubro.

Material examinado: BRASIL. Distrito Federal: DF-205, Fazenda Acre, região da Fercal, 10-X-1999, M.M. Augusto 1 (CEN).

Material adicional examinado: BRASIL. MinAS Gerais: Unaí, mata ao lado do túnel de fuga, 8-XI-2006, A.A. Santos 1618 (CEN).

Status de Conservação - Considerando apenas um registro de herbário; considerando o fato de vegetar apenas em Matas Mesofíticas sobre afloramento calcário (sujeitas a diversas situações de ameaça, como por exemplo: extração mineral, incêndios freqüentes, extração de madeira, desmatamentos para agricultura, remanescentes florestais fragmentados e expansão de área urbana) e por não haver registros em Áreas Protegidas de Preservação Integral ou apenas em Áreas Protegidas de Uso Sustentável (APA), no Distrito Federal, a espécie pode ser considerada como localmente criticamente em perigo - CR B1ab (ii, iii).

Cohniella Pfitzer, Nat. Pflanzenfam. 2 (6): 194. 1889.

Ervas epífitas ou rupícolas. Rizoma curto entre os caules secundários. Caules secundários intumescidos em pseudobulbos, pequenos (em relação ao comprimento da folha), suborbicular, protegidos por bainhas escariosas (finas, secas e membranáceas), encimados por um folha. Folha terete, unifacial, carnosa, articulada, muitas vezes verde com pontuações roxas ou vermelhas. Inflorescência lateral, geralmente paniculada, raramente racemosa, comprimento maior que a folha, pouco a multiflora. Flores ressupinadas, vistosas, geralmente amarelas ou brancas pintalgadas de castanho. Sépalas e pétalas livres e similares, geralmente verdes ou amarelas com pontos ou manchas vermelhas ou castanhas. Labelo trilobado, ecalcarado, base do labelo inserido perpendicularmente na base da coluna, lobo apical geralmente muito maior que os laterais; região do disco com calo composto por séries de placas e/ ou dentes. Coluna relativamente curta, com asas semicirculares ou estelídios ladeando o estigma; proeminente tábula infraestigmática presente na base; 


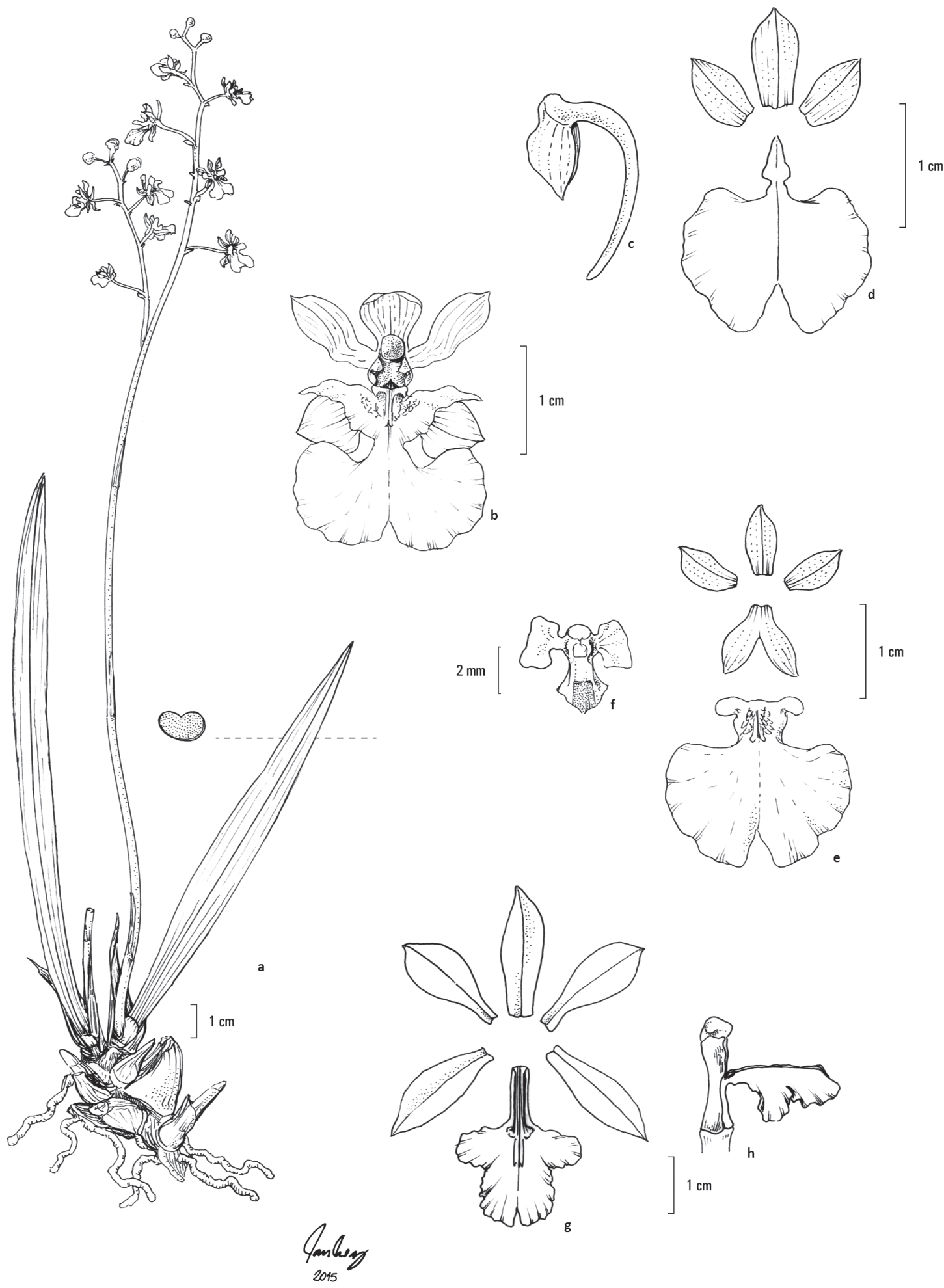

Figura 1. a-b. Cohniella cepula. a. Hábito. b. Flor. c-d. Comparettia coccinea. c. Sépalas laterais fundidas (esporão nectarífico). d. Flor aberta. e-f. Coppensia hydrophila. e. Flor aberta; f. Coluna, asas ou estelídios e tábula infraestigmática. g-h. Aspasia variegata. g. Flor aberta. h. labelo inserido na parte mediana da coluna. (a-b. Pellizzaro 30; c-d. Bianchetti 1460; e-f. Batista 337; g-h. Augusto 1).

Figure 1. a-b. Cohniella cepula. a. Habit. b. Flower. c-d. Comparettia coccinea. c. Sepals fused lateral (nectar spur). d. Open flower. e-f. Coppensia hydrophila. e. Open flower; f. Column, wings on sides and tabula infrastigmatica. g-h. Aspasia variegata. g. Open flower. h. labelum inserted in the median part of the column. (a-b. Pellizzaro 30; c-d. Bianchetti 1460; e-f. Batista 337; g-h. Augusto 1). 
clinândrio pouco desenvolvido, liso. Fruto cápsula elipsóide a suborbicular, não a levemente 3-angulada; frutos maduros com ápice dos carpelos unidos.

O gênero Cohniella possui cerca de 17 espécies (conhecidas como rat-tail oncidiums ou Oncidium rabo-de-rato, devido à morfologia das folhas), amplamente distribuídas desde o norte do México até o norte da Argentina e Brasil (Cetzal Ix et al. 2012). No Brasil ocorrem cinco espécies em quase todos os biomas, exceto no bioma Pampa (Cetzal Ix et al. 2012). No bioma Cerrado estão representadas duas espécies, Cohniella cepula (Hoffmanns.) Carnevali \& G.A. Romero e Cohniella jonesiana (Rchb. f.) Christenson, que também ocorrem no Distrito Federal.

\section{Chave para as espécies de Cohniella do Distrito Federal}

1. Folha geralmente ereta; sépalas e pétalas geralmente de comprimento menor que o labelo (pétalas e sépalas 0,6-1,5 cm comp.; labelo 1,3-1,6 cm comp.); labelo amarelo; calo do labelo tridentado 1. C. cepula

1. Folha sempre pendente; sépalas e pétalas geralmente do mesmo comprimento ou pouco menores que o labelo (pétalas e sépalas 1,6-2,5 cm comp.; labelo 2-2,5 cm comp.); labelo branco; calo do labelo pentadentado ... 2. C. jonesiana

Cohniella cepula (Hoffmanns.) Carnevali \& G.A. Romero, Brittonia 62(2): 167. 2010.

Figura $1 \mathrm{a}-\mathrm{b}$

Pseudobulbos 0,5-0,7 × 0,3-0,7 cm, verdes, protegidos por bainhas paleáceas persistentes, pequenas. Folha 2,5-17,5 × 0,2-1 cm, séssil, estreitolinear, suculenta, verde, base truncada, ápice agudo. Inflorescência 32-72,5 cm compr., paniculada, 10-25 flores. Flores pediceladas, pedicelos, 0,9-1,6 cm compr. Sépalas similares, rombóides a largo-elípticas, membranáceas, amareladas densamente pintalgadas de castanho-avermelhado, base atenuada, margem inteira, ápice obtuso; sépala dorsal, 0,6-1 × 0,3-0,7 cm; sépalas laterais $0,8-1,5 \times 0,4-0,7 \mathrm{~cm}$, livres. Pétalas 0,6-0,9 × 0,3-0,6 cm, obovadas, membranáceas, amareladas, densamente pintalgadas de marromavermelhado, base atenuada, margem levemente ondulada, ápice obtuso. Labelo 1,3-1,6 × 1,1-1,7 cm, trilobado, amarelo; lobos laterais 2-5 $\times 4-7 \mathrm{~mm}$, obovados a triangulares, no mesmo plano do lobo mediano, amarelos; lobo mediano 0,6-0,9 × 1,1-1,7 cm, oboval a espatulado, margem pouco erosa, ápice emarginado; istmo 3-5 mm, amarelo; região do disco com calo tridentado e duas quilhas laterais. Coluna 2-4 $\times$ ca. $1 \mathrm{~mm}$, castanha; tábula infraestigmática 1-2 $\times$ ca. $1 \mathrm{~mm}$; asas ou estelídios 1-2 × 1-2 mm. Fruto não visto.

A espécie Cohniella cepula ocorre na Argentina, Bolívia, Paraguai, Peru e Brasil (Cetzal Ix et al. 2012). No Brasil, distribui-se no Distrito Federal e nos Estados do Acre, Goiás, Maranhão, Mato Grosso, Mato Grosso do Sul, Pará, Rio de Janeiro, Rondônia e Tocantins (Cetzal Ix et al. 2012, CRIA 2015). No Distrito Federal, vegeta em mata ciliar e mata mesofítica decídua, e floresce especialmente entre os meses de abril e junho.

Material selecionado: BRASIL. Distrito Federal: APA de Cafuringa, próximo à República dos Urubus, 25-V-2006, K.F. Pellizzaro 30 (CEN). FERCAL, Afloramento Calcário na DF-205 leste, 5-VI-1992, J.A.N. Batista 306 (CEN). Núcleo Rural Sobradinho II, Chacará Tupã-Ipê, 23-V-2007, R.A. Mendes 339 (CEN).

Status de Conservação - Considerando os seis registros de herbário; considerando o fato de vegetar apenas em Matas Mesofíticas sobre afloramento calcário (sujeitas a diversas situações de ameaça, como por exemplo: extração mineral, incêndios frequentes, extração de madeira, desmatamentos para agricultura, remanescentes florestais fragmentados e expansão de área urbana); por apresentar potencial ornamental configurando potencial de exploração (pressão de coleta e comercialização) e por não haver registros em Áreas Protegidas de Preservação Integral ou apenas em Áreas Protegidas de Uso Sustentável (APA), no Distrito Federal, a espécie pode ser considerada como localmente em perigo - EN A2d + B1ab (ii, iii).

\section{Cohniella jonesiana (Rchb. f.) Christenson,} Lindleyana. 14(4): 177. 1999.

Pseudobulbos 0,6-1,1 × 0,3-1 cm, verdes, protegidos por bainhas paleáceas persistentes, pequenas. Folha 2,2-40 × 0,2-2 cm, séssil, estreitolinear, suculenta, verde-escura, base truncada, ápice agudo. Inflorescência 30-70 cm compr., paniculada, 2-10 flores. Flores pediceladas, pedicelos, 2-2,5 cm compr. Sépalas similares, obovadas a oblanceoladas, membranácea, brancas densamente pintalgadas de castanho-avermelhado, base profundamente atenuada, margem inteira, encrespada, ápice obtuso; sépala dorsal 1,6-2,5 × 0,8-1,3 cm; sépalas 
laterais $1,8-2,4 \times 0,8-1,2 \mathrm{~cm}$, parcialmente fundidas na base. Pétalas 2-2,6 $\times 0,8-1 \mathrm{~cm}$, oblongas a oblanceoladas, membranáceas, brancas densamente pintalgadas de castanho-avermelhado, base atenuada, margem levemente ondulada, ápice obtuso. Labelo 2-2,5 $\times 2-2,6 \mathrm{~cm}$, branco pintalgado de vermelho na base; lobos laterais $0,3-0,6 \times 0,5-0,9 \mathrm{~cm}$, oblongos, no mesmo plano do lobo mediano, brancos, margens erosas; lobo mediano 1,2-2 × 2-2,6 cm, oboval a espatulado, margem erosa a lacerada, ápice emarginado; istmo 1-3 cm, amarelo; região do disco com calo pentadentado, dente central comprimido lateralmente ladeado por quatro dentes menores (dois posteriores e dois anteriores). Coluna ca. $6 \times 2-4 \mathrm{~mm}$, castanha; tábula infraestigmática 2-3 × 1-3 mm; asas ou estelídios 1,5-2 × 1-3 mm. Fruto não visto.

A espécie Cohniella jonesiana ocorre desde a Argentina, Bolívia, Brasil até o Paraguai (Cetzal Ix et al. 2012). No Brasil, distribui-se no Distrito Federal, e nos Estados de Espírito Santo, Mato Grosso do Sul, Minas Gerais, Paraná e São Paulo (Cetzal Ix et al. 2012, CRIA 2015). Segundo Pellizzaro et al. (2004) a espécie vegeta, no Distrito Federal, em mata mesofítica sobre afloramento calcário e floresce nos meses dezembro a fevereiro.

Não foram encontrados vouchers de herbário para a espécie. Entretanto, trabalhos como o estudo do gênero Oncidium (Pellizzaro et al. 2004) e o tratamento da família Orchidaceae na APA de Cafuringa e sua contribuição para a diversidade da flora do Distrito Federal e do bioma Cerrado (Bianchetti et al. 2005) registram a ocorrência da espécie para o DF.

A descrição botânica foi realizada a partir do material adicional examinado de Minas Gerais, com adaptações da descrição contida no trabalho de Cetzal Ix et al. (2012).

Material adicional examinado: BRASIL. MinAS GERAIS: Unaí, Região da Gruta do Tamboril, 12-X-2007. Z.J.G. Miranda 93 (CEN).

Status de Conservação - Considerando apenas um exemplar em cultivo (sem registro de herbário); considerando o fato de vegetar apenas em Matas Mesofíticas sobre afloramento calcário (sujeitas a diversas situações de ameaça, como por exemplo: extração mineral, incêndios frequentes, extração de madeira, desmatamentos para agricultura, remanescentes florestais fragmentados e expansão de área urbana); por apresentar potencial ornamental configurando potencial de exploração (pressão de coleta e comercialização) e por não haver registros em
Áreas Protegidas de Preservação Integral ou apenas em Áreas Protegidas de Uso Sustentável (APA), no Distrito Federal, a espécie pode ser considerada como localmente criticamente em perigo - CR A2d + $\mathrm{B} 1 \mathrm{ab}(\mathrm{ii}, \mathrm{iii})$ ou localmente extinta na natureza.

Comparettia Poepp. \& Endl., Nov. Gen. Sp. Pl. 1: 42. t. 73.1835.

Ervas epífitas. Rizoma curto entre os caules secundários. Caules secundários intumescidos em pseudobulbos, alongados a orbiculares, encimados por 1-4 folhas. Folhas conduplicadas, bifaciais, coriáceas, articuladas, geralmente verdes, às vezes pigmentadas de vermelho-escuro. Inflorescência lateral, tipo racemo, normalmente excedendo o comprimento das folhas, 5-25 flores. Flores ressupinadas, vistosas, vermelhas, alaranjadas, amarelas a rosadas. Sépala dorsal livre, as laterais fundidas formando esporão nectarífico. Pétalas livres. Labelo hastado, inteiro, calcarado, base do labelo inserido perpendicularmente na base da coluna, base com dois prolongamentos filiformes divergentes (posicionados dentro do esporão formado pelas sépalas laterais); lobo apical aplanado, bem desenvolvido; região do disco com calo simples, elevado. Coluna não alada, reta; tábula infraestigmática ausente na base; clinândrio pouco desenvolvido, liso. Fruto cápsula elíptica a ovóide, não a levemente 3 -angulada; frutos maduros com ápice dos carpelos unidos.

O gênero Comparettia possui cerca de 60 espécies distribuídas desde o México e Índias Ocidentais até a América do Sul, englobando a Bolívia, Peru e Brasil (Chase 2009). No Brasil, ocorrem cinco espécies nos biomas Amazônia, Cerrado e Mata Atlântica. No bioma Cerrado ocorre apenas uma espécie, Comparettia coccinea Lindl., que também está presente no Distrito Federal (Barros et al. 2015).

Comparettia coccinea Lindl., Sketch Veg. Swan R. 24: t. 68. 1838.

Figura $1 \mathrm{c}-\mathrm{d}$

Pseudobulbos 0,8-2,5 × 0,2-0,5 cm, oblongos, verdes, protegidos por bainhas paleáceas persistentes, encimados por 1 folha. Folha 8,2-21,2 $\times 0,8-1,5 \mathrm{~cm}$, séssil, lanceolada, verde, base atenuada, ápice obtuso. Inflorescência 8,3-31 cm compr., 1-6 flores. Flores pediceladas, pedicelos, 1,1-1,5 cm compr. Sépalas similares, ovais, membranáceas, rubro-alaranjadas, base levemente atenuada, margem inteira, ápice agudo a mucronado; sépala dorsal ca. $8 \times 4 \mathrm{~mm}$; sépalas laterais 5-6 $\times$ ca. $3 \mathrm{~mm}$, fundidas, esporão 
$2 \mathrm{~cm}$. Pétalas 5-7 × 3-4 mm, ovais, membranáceas, rubro-alaranjadas, base atenuada, margem inteira, ápice agudo. Labelo ca. 1,6 × 1,6 cm, obovado, rubroalaranjado com parte inferior levemente amarelada, base cuneada, margem sinuada, ápice emarginado; região do disco com calo bilamelado. Coluna 2-3 mm, esbranquiçada. Fruto ca. $2 \times 1,5 \mathrm{~cm}$, elipsóide.

A espécie Comparettia coccinea ocorre na Bolívia, Peru e Brasil (Tropicos 2014). No Brasil, distribui-se no Distrito Federal e nos Estados da Bahia, Espírito Santo, Minas Gerais, Pernambuco, Rio de Janeiro e São Paulo (Barros et al. 2015). No Distrito Federal, vegeta em mata ciliar alagada, com floração nos meses de janeiro a março, e frutificando a partir do mês de março até outubro.

Material selecionado: BRASIL. Distrito Federal: Parque Nacional de Brasília, Mata dos Três Barras, 30-III-1999, A.A. Santos 398 (CEN). Reserva Ecológica do Guará, 18-X-1994, R.S. Oliveira 16 (UB). Taguatinga, Floresta Nacional de Brasília, 14-X-2012, J.H. Lima 16 (UB). Várzea Bonita, 9-II-1978, E.P. Heringer 16751 (IBGE).

Status de Conservação - Considerando os seis registros de herbário; considerando o fato de vegetar em Matas Ciliares ou de Galeria (sujeitas a diversas situações de ameaça, como por exemplo: extração de madeira, desmatamentos para agricultura, remanescentes florestais fragmentados e expansão de área urbana); por apresentar potencial ornamental configurando potencial de exploração (pressão de coleta e comercialização) e por haver metade dos registros em Áreas Protegidas de Preservação Integral, no Distrito Federal, a espécie pode ser considerada como localmente em perigo - EN A2cd + B1ab (ii, iii).

Coppensia Dumort., Nouv. Mém. Acad. Roy. Sci. Bruxelles. 9 (3): 10. 1835.

Ervas terrícolas, epífitas ou rupícolas. Rizoma curto a alongado entre os caules secundários. Caules secundários intumescidos em pseudobulbos, fusiformes a ovais, geralmente rugosos e ancipitados, parcialmente recobertos por bainhas foliares, encimados por 2-4 folhas. Folhas conduplicadas, bifaciais, coriáceas, articuladas, verdes. Inflorescência lateral, tipo racemo ou panícula, comprimento maior que as folhas, pauci- a multiflora. Flores ressupinadas, explanadas e vistosas, geralmente amarelas com pintas castanhas ou vermelhas. Sépala dorsal livre; sépalas laterais fundidas em várias medidas. Pétalas livres, semelhantes às sépalas em tamanho, forma e cor.
Labelo trilobado, ecalcarado, base do labelo inserido perpendicularmente na base da coluna, lobos laterais auriculados, lobo intermediário geralmente bastante amplo; região do disco com calo multiverrucoso ou lamelado, margem do disco e istmo inteira, nunca denteada ou fimbriada. Coluna com asas semicirculares ou estelídios ladeando o estigma; proeminente tábula infraestigmática presente na base; clinândrio pouco desenvolvido, liso. Fruto cápsula elíptica a ovóide, não a levemente 3-angulada; frutos maduros com ápice dos carpelos unidos.

O gênero Coppensia possui cerca de 50 espécies (WCSP 2014) com distribuição neotropical na Bolívia, Paraguai, Argentina, Uruguai e Brasil. No Brasil ocorrem 38 espécies (29 endêmicas) em todos os biomas, porém com baixíssima representação nos biomas Amazônia e Caatinga. No bioma Cerrado estão representadas 15 espécies e dessas, duas ocorrem no Distrito Federal (Coppensia hydrophila (Barb. Rodr.) Campacci e Coppensia varicosa (Lindl.) Campacci (Barros et al. 2015).

\section{Chave para as espécies de Coppensia do Distrito Federal}

1. Ervas terrícolas, inflorescência tipo racemo 1. C. hydrophila

1. Ervas epífitas, inflorescência tipo panícula 2. C. varicosa

Coppensia hydrophila (Barb. Rodr.) Campacci, Bol. CAOB 62: 55. (2006).

Figura $1 \mathrm{e}-\mathrm{f}$

Ervas terrícolas. Pseudobulbos 1,9-5 × 0,9-2,6 cm, esverdeados, protegidos lateralmente por bainhas foliosas $8-42,5 \mathrm{~cm}$ compr., persistentes, articuladas, encimados por 2-3 folhas. Folhas 10,2-24 × 1,3-3,5 cm, sésseis, estreitamente elípticas a oblanceoladas, bases atenuadas, ápices agudos. Inflorescência 0,6-1 m compr., tipo racemo, 5-40 ou mais flores. Flores pediceladas, pedicelos, 0,7-2 cm compr. Sépalas similares, elípticas, membranáceas, totalmente amarelas ou levemente pintalgadas de castanhovináceo, bases levemente estreitadas, margens inteiras, ápices obtusos; sépala dorsal 5-7 × 2-4 mm; sépalas laterais $5-9 \times 1-3 \mathrm{~mm}, 1 / 3$ adnatas. Pétalas 5-7 $\times 3-5 \mathrm{~mm}$, obovadas, membranáceas, totalmente amarelas ou levemente pintalgadas de castanhovináceo, base levemente estreitadas, margens inteiras, ápices agudos, apiculadas. Labelo 1,4-1,8 × 1,6-2 cm, amarelo; lobos laterais 1-4 × 2-4 mm, transversalmente 
elípticos, amarelos; lobo mediano 0,8-1,3 × 1,6-2 cm, oval, margem sinuada, ápice emarginado; istmo 2-3 mm, amarelo; região do disco com calo verrucoso envolvendo estruturas dentiformes e cristas (região mediana bidentado; região anterior tricristado). Coluna 3-5 × 1-1,5 mm, castanha, asas ou estelídios 2-3 $\times 1-2 \mathrm{~mm}$, tábula infraestigmática ca. $2 \times 1-2 \mathrm{~mm}$. Fruto não visto.

A espécie Coppensia hydrophila ocorre no Paraguai e Brasil (Tropicos 2014). No Brasil, distribui-se no Distrito Federal e nos Estados da Bahia, Espírito Santo, Goiás, Minas Gerais, Paraná, Pernambuco, Rio de Janeiro, Rio Grande do Sul, Santa Catarina, São Paulo e Tocantins (Barros et al. 2015). No Distrito Federal, vegeta em ambientes de campo úmido, brejo e campo rupestre, e floresce nos meses de outubro a janeiro.

Material selecionado: BRASIL. Distrito Federal: Below Velhacap, Close to Núcleo Bandeirante, 8-XI-1978, J. Ratter 4293 (UB). Fazenda Água Limpa da UnB, Córrego Taquara, 7-XI-2003, E.R. Pinagés.n. (UB14529). Lago Sul, campo às margens do Córrego do Gama, 6-I-1990, J.A.N. Batista 54 (CEN). Parque Boca da Mata, 24-XI-1995, J.M. Rezende 255 (CEN). Reserva Ecológica do Guará, 3-X-1990, J.A.N. Batista 118 (CEN). Reserva Ecológica do IBGE, 25-X-1979, E.P. Heringer 3744 (IBGE). Santuário Ecológico do Riacho Fundo, 29-XI-1994, R.S. Oliveira 28 (UB). Setor Industrial, 10-XII-1965, R.P. Belém 1896 (UB).

Status de Conservação - Considerando os quinze registros de herbário; considerando o fato de vegetar apenas em ambientes ricos em umidade como Campo Úmido e Brejos (sujeitos a situações de ameaça, como por exemplo: drenagem para agricultura e expansão de área urbana) e por haver boa parte dos registros em Áreas Protegidas de Preservação Integral, no Distrito Federal, a espécie pode ser considerada como localmente quase ameaçada - NT.

Coppensia varicosa (Lindl.) Campacci, Bol. CAOB. 62: 56. 2006.

Ervas epífitas. Pseudobulbos 3,5-7,8 $\times 0,9-2,8 \mathrm{~cm}$, ovado-oblongos, verdes com sulcos pintalgados de castanho-vináceo, protegidos por bainhas foliáceas $7,1-15,5 \mathrm{~cm}$, articuladas, persistentes, encimados por 2-3 folhas. Folhas 16-30 × 1-4 cm, elípticas a obovaladas, base atenuadas, ápices agudos. Inflorescência 80-116 cm compr., tipo panícula, 20 a pouco mais de 100 flores. Flores pediceladas, pedicelos 1,2-3,1 cm compr. Sépalas similares, elípticas, membranáceas, amarelas pintalgadas de castanho-avermelhado, bases levemente estreitadas, margens inteiras, ápices agudos; sépala dorsal $0,7-1,2 \times 0,3-0,6 \mathrm{~cm}$; sépalas laterais $0,8-1,5 \times 0,2-0,6 \mathrm{~cm}$, adnatas $1 / 3$ até metade. Pétalas 0,8-1,2 × 0,3-0,7 cm, ovais, membranáceas, amarelas pintalgadas de marrom-avermelhado, bases atenuadas, margens levemente sinuosas, ápices obtusos, mucronados. Labelo 2,3-3,5 × 2,2-4,1 cm, amarelo; lobos laterais $0,3-0,5 \times 0,3-0,5 \mathrm{~cm}$, obovados a sub-rotundados, amarelos; lobo mediano 1,4-3 × 2,2-4,1 cm, largo-reniforme, levemente constrito em direção ao ápice dando a impressão de ser tetra-lobado, ápice emarginado; região do disco geralmente pintalgada de marrom-avermelhado com calo verrucoso envolvendo estruturas dentiformes e cristas (região mediana bidentado; região anterior tri-cristado). Coluna 4-5 $\times$ ca. $1 \mathrm{~mm}$, castanha, asas ou estelídios ca. $3 \times 1-2 \mathrm{~mm}$, tábula infraestigmática ca. $2 \times 1 \mathrm{~mm}$. Fruto não visto.

A espécie Coppensia varicosa ocorre na Bolívia, Paraguai e Brasil (Tropicos 2014). No Brasil, distribui-se no Distrito Federal e nos Estados da Bahia, Goiás, Minas Gerais, Paraná, Santa Catarina e São Paulo (Barros et al. 2015). No Distrito Federal, vegeta em ambiente de mata ciliar, mata ciliar seca e mata de galeria e floresce principalmente nos meses de janeiro a abril.

Material selecionado: BRASIL. Distrito Federal: ARIE Cerradão, 31-I-2008, J.S. Silva 318 (UB). Bacia do Rio São Bartolomeu, 18-VII-1979, E.P. Heringer 1831 (IBGE). Cabeça de Veado, 6-III-1961, E.P. Heringer 8065 (UB). Catetinho, 15-II-1979, A.E.H. Salles 3 (IBGE). EEJBB, Captação d'água do JBB, 8-IV-2003, A.C.A. Soares s.n. (HEPH29268). Fazenda da Universidade de Brasília (Fazenda Água Limpa), Mata do Córrego do Gama, 16-III-1992, L. Bianchetti 1239 (CEN). Fazenda Sucupira, Córrego do Açudinho, 7-II-2000, J.G. Faria 254 (CEN). Grota atrás do cemitério do Gama, 17-IX-1996, S.M. Gomes 86 (CEN). Reserva Ecológica do IBGE, Córrego Taquara, 17-III-1994, B.M.T. Walter 2091 (CEN).

Status de Conservação - Considerando os quatorze registros de herbário; considerando o fato de vegetar em Matas Ciliares ou de Galeria (sujeitas a diversas situações de ameaça, como por exemplo: extração de madeira, desmatamentos para agricultura, remanescentes florestais fragmentados e expansão de área urbana); por apresentar potencial ornamental configurando potencial de exploração (pressão de coleta e comercialização) e por haver boa parte dos 
registros em Áreas Protegidas de Preservação Integral, no Distrito Federal, a espécie pode ser considerada como localmente vulnerável - VUA2cd + B1ab (ii, iii).

Ionopsis Kunth, Nov. Gen. Spec. Pl. 1: 348, t. 83. 1816.

Ervas epífitas. Rizoma curto entre os caules secundários. Caules secundários intumescidos em pseudobulbos, inconspícuos, encimados por 1 folha. e sempre encobertos lateralmente por 2-4 bainhas foliosas. Folhas conduplicadas, bifaciais, coriáceas, articuladas, verdes ou arroxeadas. Inflorescência lateral, tipo panícula, comprimento maior que as folhas, uni- a multiflora. Flores ressupinadas, explanadas e vistosas, verdes, rosadas a violetas. Sépala dorsal livre; sépalas laterais parcialmente fundidas e na base formando pequeno mento. Pétalas livres, similares às sépalas. Labelo inteiro, obovado, ecalcarado, base do labelo inserido perpendicularmente na base da coluna, região médio-apical bastante dilatada, ápice emarginado; região do disco com calo bilamelado. Coluna não alada, levemente dilatada no ápice; tábula infraestigmática ausente; clinândrio pouco desenvolvido, liso. Fruto cápsula elíptica a ovóide, não a levemente 3 -angulada; frutos maduros com ápice dos carpelos unidos.

O gênero Ionopsis possui três espécies amplamente distribuídas no Neotrópico, desde o sul da Flórida, até a América Central e do Sul (Chase 2009). No Brasil, ocorrem três espécies nos biomas Amazônia, Cerrado, Mata Atlântica. No bioma Cerrado, e no Distrito Federal, está representada por apenas uma espécie, Ionopsis utricularioides (Sw.) Lindl. (Barros et al. 2015).

Ionopsis utricularioides (Sw.) Lindl., Coll. Bot. 8: t. 39, f. A. 1826.

Figura 3 e-f

Pseudobulbos $0,4-2,7 \times 0,1-0,8 \mathrm{~cm}$, elípticos a ovóides, verdes, escondidos por bainhas. Folhas ou bainhas foliosas 5-15,2 $\times 0,8-1,2 \mathrm{~cm}$, com limbo desenvolvido, persistentes, oblongas ou linearliguladas. Inflorescência 21-66 cm comp., 9-150 ou mais flores. Flores pediceladas, pedicelos, $0,4-1 \mathrm{~cm}$ compr. Sépalas similares, ovaladas a elípticas, membranáceas, lilases, bases atenuadas, margens inteiras, ápices agudos; sépala dorsal 4-5 × 1-2 mm; sépalas laterais 4-5 × 1-2 mm, fundidas até a metade. Pétalas 4-6 $\times 2-3 \mathrm{~mm}$, obovadas, membranáceas, lilases, bases atenuadas, margens inteiras, ápices obtusos. Labelo 0,8-2 × 1-1,5 cm, lilás a branco, base cuneada, margem inteira, ápice emarginado. Coluna 1-2 mm comp., acastanhada. Fruto não visto.

A espécie Ionopsis utricularioides ocorre em parte da América do Norte, Central e do Sul, desde a Flórida (EUA) até Argentina e Brasil (Aguiar 2014). No Brasil, distribui-se no Distrito Federal e nos Estados do Acre, Amazonas, Bahia, Goiás, Pará, Paraná, Pernambuco, Maranhão, Mato Grosso, Mato Grosso do Sul, Minas Gerais, Rio de Janeiro, Rondônia, Sergipe, Santa Catarina e São Paulo (Barros et al. 2015). No Distrito Federal, ocorre em mata de galeria inundada e mata mesofítica, e floresce nos meses de junho a dezembro.

Material selecionado: BRASIL. Distrito Federal: APA de Cafuringa, República dos Urubus, 18-XII-2002, K.F. Pellizzaro 28 (CEN). FERCAL, APA de Cafuringa, 9-VIII-1990, R. Vieira 361 (CEN). Jardim Botânico de Brasília, 28-VIII-2000, M.G. Nóbrega 1294 (HEPH). Reserva Ecológica do Guará, 31-VIII-1999, J.A.N. Batista 935 (CEN). Margem do Ribeirão Jacaré, cortada pela DF-100, 16-VI-1991, L. Bianchetti sn. (CEN15096).

Status de Conservação - Considerando os sete registros de herbário; considerando o fato de vegetar em Matas de Galeria Inundáveis e Matas Mesofíticas (sujeitas a diversas situações de ameaça, como por exemplo: drenagem para agricultura, extração de madeira, desmatamentos para agricultura, remanescentes florestais fragmentados e expansão de área urbana); por apresentar potencial ornamental configurando potencial de exploração (pressão de coleta e comercialização) e por haver boa parte dos registros em Áreas Protegidas de Preservação Integral, no Distrito Federal, a espécie pode ser considerada como localmente em perigo - EN A2cd + B1ab (ii, iii).

Lockhartia Hook., Bot. Mag. 54: t. 2715. 1827.

Ervas epífitas. Rizoma curto entre os caules secundários. Caules secundários não intumescidos em pseudobulbos, eretos ou pêndulos, cobertos por folhas curtas. Folhas unifaciais, carnosas, bases equitantes ou imbricadas, não-articuladas, verdes. Inflorescência curta, lateral ou terminal, tipo racemo ou panícula, comprimento menor ou igual às folhas, pauciflora; brácteas alargadas, semiorbiculares. Flores geralmente ressupinadas, pequenas, geralmente amarelas com manchas vermelhas ou castanho-escuras. Sépalas e pétalas livres, semelhantes em tamanho e forma. Labelo geralmente trilobado, ecalcarado, base do labelo inserido perpendicularmente na base da coluna, 
lobo apical bilobado, oblongo a quase circular; lobos laterais muitas vezes lineares e arqueados; região do disco com calo simples a complexo, tuberculado ou com chifres. Coluna geralmente alada ou com pequenas asas ladeando o estigma; tábula infraestigmática ausente; clinândrio pouco desenvolvido, liso. Fruto cápsula elipsóide a suborbicular, não a 3-angulada; frutos maduros com ápice dos carpelos livres e reflexos.

O gênero Lockhartia possui cerca de 30 espécies de distribuição neotropical, que se estende da América do Norte (México) a América do Sul (Venezuela, Guiana Francesa, Bolívia, Peru, Trinidad e Brasil) (Chase 2009). No Brasil, ocorrem sete espécies (quatro endêmicas), distribuídas nos biomas Amazônia, Mata Atlântica e Cerrado (Barros et al. 2015). No bioma Cerrado, ocorre apenas uma espécie, Lockhartia goyazensis Rchb. f., que está presente no Distrito Federal (Barros et al. 2015).

\subsection{Lockhartia goyazensis Rchb. f. Bot. Zeitung} (Berlin). 10: 768. 1852.

\section{Figura $2 \mathrm{a}-\mathrm{b}$}

Folhas 1-2,3 × 0,3-1,4 cm, sésseis, triangulares, em vista lateral, e largamente ovadas, em vista frontal distendida, base truncada, ápice agudo a levemente rotundado. Inflorescência do tipo racemo, 2-4 flores, 1-1,6 cm comp.; brácteas 2-4, petalóides, patentes, ovais, ápice agudo, castanho-claras, 2-4 mm compr. Flores pediceladas, pedicelos 1-7 mm compr. Sépalas 3-4 × 2-3 mm, obovadas, membranáceas, amarelas, bases truncadas, margens inteiras, ápices obtusos. Pétalas 3-4 × 2-3 mm, elípticas, membranáceas, amarelas, bases truncadas, margens inteiras, ápices rotundados. Labelo 5-6 × 7-9 mm, amarelo com manchas castanhas no centro; lobos laterais 3-4 $\times$ ca. 0,8 mm, lineares, amarelos; lobo mediano 3-4 $\times 3-5 \mathrm{~cm}$, obovado-subquadrado, margem repanda, ápice emarginado; região do disco com calo complexo, tuberculoso, ocupando a parte basal e central do lobo mediano. Coluna ca. $2 \times 1 \mathrm{~mm}$, castanha. Fruto ca. $11 \times 6 \mathrm{~mm}$, oblongo.

A espécie Lockhartia goyazensis ocorre na Bolívia e Brasil (Tropicos 2014). No Brasil, distribui-se no Distrito Federal e nos Estados do Amapá, Amazonas, Espírito Santo, Goiás, Maranhão, Mato Grosso, Mato Grosso do Sul, Minas Gerais, Pará, Pernambuco, Rondônia, Sergipe e Tocantins (Barros et al. 2015). No Distrito Federal, ocorre em mata mesofítica de encosta e mata de galeria, florescendo nos meses de julho a outubro, e frutificando nos meses de outubro a dezembro.
Material selecionado: BRASIL. Distrito Federal: APA de Cafuringa, Fazenda Palestina, 2-X-1992, B.A.S. Pereira 2271 (CEN, IBGE). FERCAL, Morro da Pedreira, 15³0'40"S, 4757'36"W, 27-XI-2014, V.V. Queiroz 15 (UB). Margem direita do Rio Preto, $16^{\circ} 02^{\prime} \mathrm{S}, 47^{\circ} 19^{\prime} \mathrm{W}, 15-\mathrm{X}-2002$, J.M. Rezende 662 (CEN).

Status de Conservação - Considerando apenas 4 registros de herbário; considerando o fato de vegetar apenas em Matas Mesofíticas e Mata de Galeria (sujeitas a diversas situações de ameaça, como por exemplo: extração de madeira, desmatamentos para agricultura, remanescentes florestais fragmentados e expansão de área urbana) e por não haver registros em Áreas Protegidas de Preservação Integral ou apenas em Áreas Protegidas de Uso Sustentável (APA), no Distrito Federal, a espécie pode ser considerada como localmente em perigo - EN B1 ab (ii, iii).

Lophiaris Raf., Fl. Tellur. 4: 40-41. 1836.

Ervas epífitas. Rizoma curto entre os caules secundários. Caules secundários intumescidos em pseudobulbos, muito reduzidos, subcilíndricos, encimados por 1 folha. Folha conduplicada, bifacial, carnosa, articulada, verde, geralmente pintalgadas de roxo. Inflorescência lateral, tipo racemo ou panícula, com comprimento maior que as folhas, multiflora. Flores ressupinadas, pequenas a grandes, pouco a muito vistosas, com coloração combinada de amarela, branco, púrpura e castanho, geralmente pintalgadas. Sépalas laterais ligeiramente conatas, sépala dorsal e pétalas livres, semelhantes entre si, venação reticulada, papilosas nas superfícies externas. Labelo trilobado, ecalcarado, base do labelo inserido perpendicularmente na base da coluna; lobos laterais pequenos em relação ao lobo mediano; região do disco com calo complexo (1-2 séries de dentes, quilha central). Coluna alada, asas ou estelídeos ladeando o estígma; tábula infraestigmática presente; clinândrio pouco desenvolvido, liso. Fruto cápsula elipsóide, não a levemente 3-angulada; frutos maduros com ápice dos carpelos unidos.

O gênero Lophiaris possui cerca de 40 espécies distribuídas desde a Flórida, México, América Central, até a Argentina e Brasil (WCSP 2014). No Brasil, ocorrem seis espécies (uma endêmica), nos biomas Amazônia, Cerrado e Mata Atlântica (Barros et al. 2015). No bioma Cerrado, estão representadas duas espécies e dessas apenas Lophiaris pumila (Lindl.) Braem ocorre no Distrito Federal (Barros et al. 2015). 


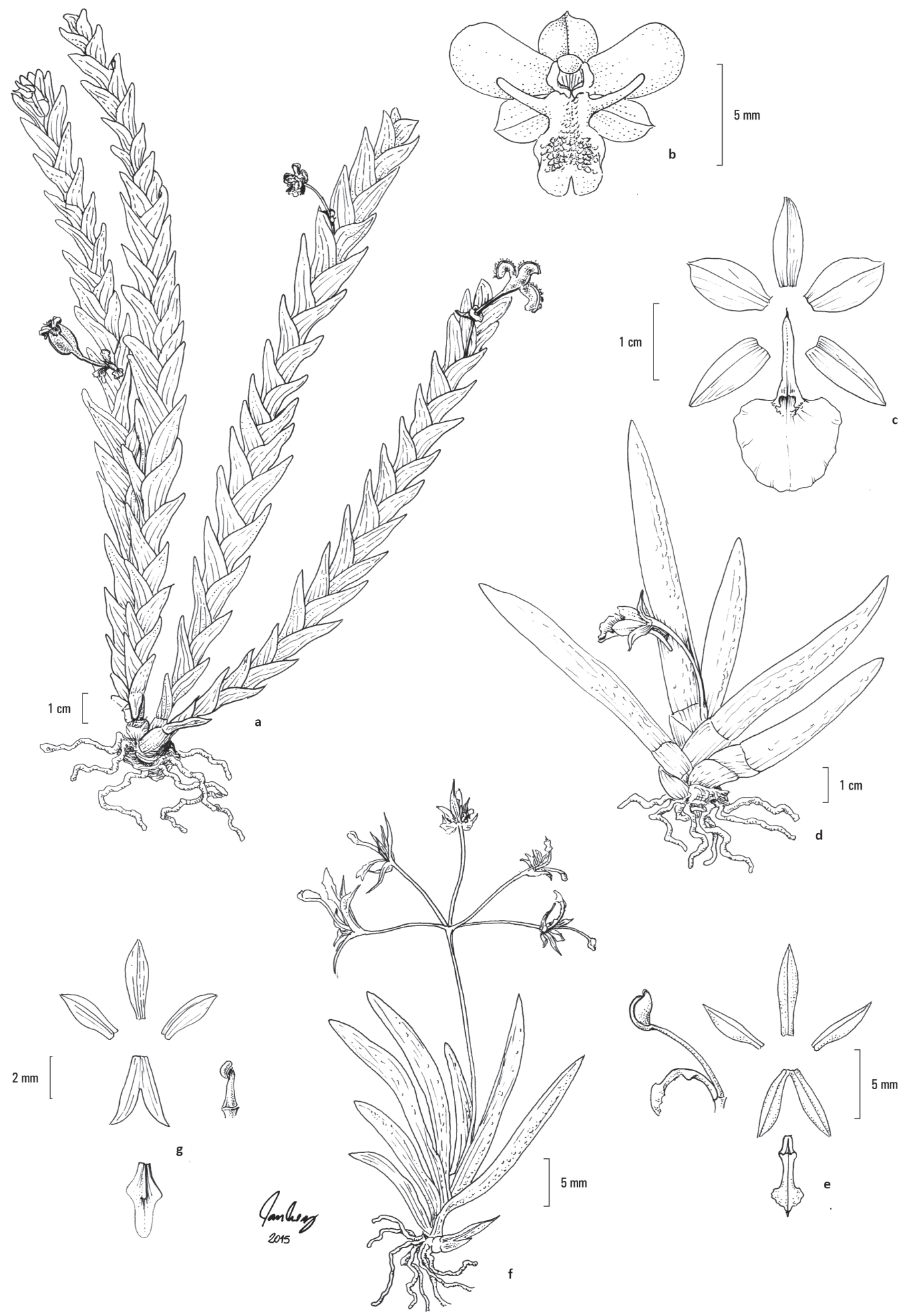

Figura 2. a-b. Lockhartia goyazensis. a. Hábito. b. Flor. c-d. Plectrophora edwallii. c. Flor aberta. d. Hábito. e-f. Macroclinium wullschlaegelianum. e. Flor aberta e coluna. f. Hábito. g. Notylia lyrata. Flor aberta e coluna. (a-b. Pereira 2271; c-d. Batista 95; e-f. Batista 878; g. Pereira-Silva 7575).

Figure 2. a-b. Lockhartia goyazensis. a. Habit. b. Flower. c-d. Plectrophora edwallii. c. Open Flower. d. Habit. e-f. Macroclinium wullschlaegelianum. e. Open flower e column. f. Habit. g. Notylia lyrata. Open flower e column. (a-b. Pereira 2271; c-d. Batista 95; e-f. Batista 878; g. Pereira-Silva 7575). 


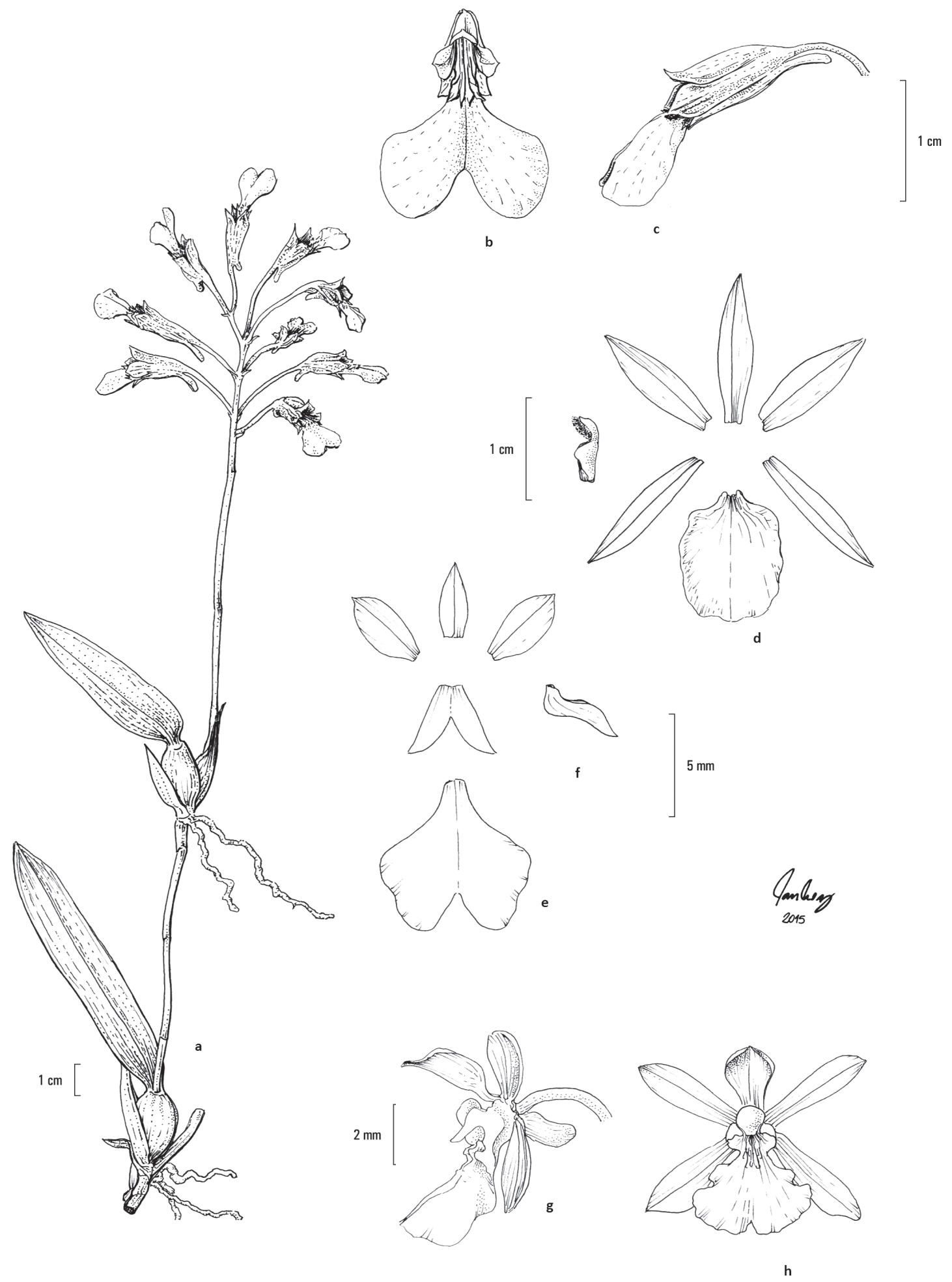

Figura 3. a-c. Rodriguezia decora. a. Hábito. b. Flor, frontal. c. Flor, lateral, sépalas formando um mento. d. Trichopilia brasiliensis. Flor aberta e coluna. e-f. Ionopsis utricularioides. e. Flor aberta. f. Sépalas laterais, formando pequeno mento (vista lateral). g-h. Trichocentrum albococcineum. g. Flor vista lateral, presença do esporão. h. Flor. (a-c. Bianchetti 853; Santos 1769; e-f. Walter 4235; g-h. Lima 55).

Figure 3. a-c. Rodriguezia decora. a. Habit. b. Flower, front. c. Flower, Lateral sepals fused forming a nectar spur. d. Trichopilia brasiliensis. Open Flower and column. e-f. Ionopsis utricularioides. e. Open Flower. f. Laterals sepals, forming a small nectar spur (side view). g-h. Trichocentrum albococcineum. g. Flower side view, presence of the spur. h. Flower. (a-c. Bianchetti 853; Santos 1769; e-f. Walter 4235; g-h. Lima 55). 
Lophiaris pumila (Lindl.) Braem, Schlechteriana. 4 (1-2): 21. 1993.

Pseudobulbos 2-8 $\times 2-3 \mathrm{~mm}$, verdes, protegidos lateralmente por bainhas paleáceas. Folha $4,4-16,5 \mathrm{~cm}$, séssil, obovada a elíptica, verde-clara, base atenuada, ápice agudo. Inflorescência 7-23,5 cm compr., tipo panícula, 60-150 ou mais flores. Flores curtamente pediceladas, pedicelos 1-2 mm compr. Sépalas similares, oval-oblongas, membranáceas, amareloqueimadas, bases atenuadas, margens inteiras, ápices obtusos; sépala dorsal 1-2 $\times 0,6-1,5 \mathrm{~mm}$; sépalas laterais $1,5-2,5 \times 0,6-1,5 \mathrm{~mm}, 1 / 3$ adnatas. Pétalas $1-2,1 \times 0,8-1,1 \mathrm{~mm}$, elípticas a subespatuladas, membranáceas, amarelo-queimadas, bases atenuadas, margens inteiras, ápices obtusos. Labelo esbranquiçado a amarelo-queimado, 2-4 ×0,8-1,1 mm, base levemente cordada; lobos laterais 1,3-1,9 × 1,5-2,1 mm, triangulo-ovados, amarelo-queimados; lobo mediano 0,5-1,7 × 0,8-1,1 $\mathrm{mm}$, obovado, amarelo, ápice inteiro, obtuso; região do disco com calo 4-carenados. Coluna 1,0-1,1 $\times 0,4-0,5 \mathrm{~mm}$, castanha, tábula infraestigmática ca. $0,5 \times 0,4-0,5 \mathrm{~mm}$, asas ou estelídios 0,3-0,5 × 0,4-0,6 mm. Fruto ca. $8 \times 5-6 \mathrm{~mm}$, oblongo a ovóide.

A espécie Lophiaris pumila ocorre na Argentina, Bolívia e Brasil (Tropicos 2014). No Brasil, distribui-se no Distrito Federal e nos Estados da Bahia, Espírito Santo, Goiás, Mato Grosso, Mato Grosso do Sul, Minas Gerais, Pará, Paraná, Rio de Janeiro, Rio Grande do Sul, Santa Catarina, São Paulo e Sergipe (Barros et al. 2015). No Distrito Federal, vegeta em ambientes de mata alagada, mata ciliar, mata de galeria, mata mesofítica decídua, mata semidecídua com afloramento calcário, e floresce nos meses de novembro a abril, e frutifica entre fevereiro e maio.

Material selecionado: BRASIL. Distrito Federal: APA de Cafuringa, Fazenda dois irmãos, 18-XII-2002, K.F. Pellizzaro 33 (CEN). Córrego Cabeça de Veado, 21-XII-1993, A.E. Ramos 577 (HEPH). DF-100 sentido BSB-Formosa, Fazenda Manga, 27-XI-2002, A.A. Santos 1698 (CEN). FERCAL, Mata a direita da DF-205, 21-I-1992, J.A.N. Batista 261 (CEN). Reserva Ecológica do Jardim Botânico de Brasília, mata de galeria do Córrego Cabeça de Veado, 9-II-2003, K.F. Pellizzaro 54 (CEN). Santuário Ecológico do Riacho Fundo, 1-II-1995, R.S. Oliveira 64 (UB). Sobradinho dos Melos, Fazenda do Sr. Benedito de Jesus A. Reis, 5-V-2005, A.E.H. Salles 3761 (HEPH).

Status de Conservação - Considerando os dez registros de herbário; considerando o fato de vegetar em diversas formações florestais, inclusive Matas Mesofíticas sobre afloramento calcário (sujeitas a diversas situações de ameaça, como por exemplo: extração mineral, drenagem para agricultura, extração de madeira, desmatamentos para agricultura, remanescentes florestais fragmentados e expansão de área urbana), e por haver boa parte dos registros em Áreas Protegidas de Preservação Integral e alguns registros em Áreas Protegidas de Uso Sustentável (APA), no Distrito Federal, a espécie pode ser considerada como localmente vulnerável - VU A2c + B1ab (ii, iii).

Macroclinium Barb. Rodr., Gen. Sp. Orch. Nov. 2: 236-237. 1882.

Ervas epífitas. Rizoma curto entre os caules secundários. Caules secundários intumescidos ou não em pseudobulbos, se presentes então reduzidos, ancipitados, encimados por 1 folha. Folha ensiforme, flabeliforme, unifacial, carnosa, articulada, verde, superfície geralmente reticulada ou rugosa. Inflorescências do tipo racemo subumbelado (com flores congestas no ápice), comprimento maior que as folhas, multiflora. Flores geralmente ressupinadas, pequenas, geralmente coloridas de branco, rosa ou roxo. Sépalas e pétalas livres, semelhantes em tamanho e forma. Labelo inteiro a levemente trilobado, espatulado a hastado, ecalcarado, base do labelo inserido perpendicularmente na base da coluna, base longo-unguiculada, terete; região do disco com calo simples, elevado. Coluna não alada, levemente reflexa, tábula infraestigmática ausente, clinândrio pouco desenvolvido, liso. Fruto cápsula elipsóide, não a levemente 3-angulada; frutos maduros com ápice dos carpelos unidos.

O gênero Macroclinium possui cerca de 40 espécies de distribuição neotropical, do México, através da América Central (exceto as Antilhas) para o Peru e Brasil (Chase 2009). No Brasil, ocorrem cinco espécies (três endêmicas) nos biomas da Amazônia e Cerrado. No bioma Cerrado, ocorre apenas uma espécie, Macroclinium wullschlaegelianum (H. Focke) Dodson, a qual está presente no Distrito Federal (Barros et al. 2015).

Macroclinium wullschlaegelianum (H. Focke) Dodson. Icon. Pl. Trop. 10: t. 939. 1984.

Figura 2 e-f

Pseudobulbos 3-7 × 1-3 mm, elípticos, castanhoesverdeados, sem bainhas. Folha 0,7-3,4 $\times 0,2-0,5 \mathrm{~cm}$, 
séssil, elíptica, base truncada, ápices agudo, verde. Inflorescência 3-7,5 cm compr., 3-10 flores. Flores pediceladas, pedicelos $0,2-1,4 \mathrm{~cm}$ compr. Sépalas similares, elíptico-lineares, membranáceas, cremes, bases atenuadas, margens inteiras, ápices acuminados; sépala dorsal 8-11 × 1-2 mm; sépalas laterais 9-10 $\times$ ca. 0,1 mm, livres. Pétalas 7-9 $\times$ ca. $1 \mathrm{~mm}$, elíptico-lineares, membranáceas, amareladas pintalgadas de roxo, bases atenuadas, margens inteiras, ápices acuminados. Labelo 7-9 × 2-3 mm, roxo; lobos laterais (aurículas) triangulares muito pouco desenvolvidos com pequena calosidade entre eles; região mediana 2-3 mm, estreitamente oblonga, base unguiculada ca. 2,5 × 0,3-0,4 mm, unguículo ca. $1 \times 0,1-0,2 \mathrm{~mm}$, região apical 4-6 $\times 2-3 \mathrm{~mm}$, cordado-triangular, margens levemente erosas. Coluna $9-10 \times 0,2-0,3 \mathrm{~mm}$, castanha. Fruto ca. $8 \times 5 \mathrm{~mm}$, oblongo.

A espécie Macroclinium wullschlaegelianum ocorre na Colômbia, Guiana Francesa, Guiana, Panamá, Peru, Suriname, Venezuela e Brasil (Tropicos 2014). No Brasil, distribui-se no Distrito Federal e nos Estados do Amazonas, Goiás, Maranhão, Pará e Rondônia (Barros et al. 2015). No Distrito Federal, ocorre em ambientes de mata ciliar e floresce nos meses de fevereiro a abril, frutificando nos meses de junho a agosto.

Material selecionado: BRASIL. Distrito Federal: Mata no entroncamento da DF-100, Ribeirão Jacaré, 23-IV-1992, L. Bianchetti 1240 (CEN). DF-130, Rio Maranhão, 15-II-1999, J.A.N. Batista 878 (CEN). Fazenda dos Guimarães, Próximo do CPAC/ EMBRAPA, 4-VIII-991, J.A.N. Batista 205 (CEN). Marginais do Rio Vicente Pires, 10-II-1961, E.P. Heringer 7898 (UB).

Status de Conservação - Considerando apenas quatro registros de herbário; considerando o fato de vegetar apenas em Mata de Galeria Inundável (sujeitas a diversas situações de ameaça, como por exemplo: extração de madeira, drenagem e desmatamento para agricultura e expansão de área urbana) e por não haver registros em Áreas Protegidas de Preservação Integral nem em Áreas Protegidas de Uso Sustentável (APA), no Distrito Federal, a espécie pode ser considerada como localmente em perigo - EN B1ab (ii, iii).

Notylia Lindl., Bot. Reg. 11: sub. t. 930. 1825.

Ervas epífitas. Rizoma curto entre os caules secundários. Caules secundários intumescidos em pseudobulbos, esféricos a estreitamente elípticos, encimados por 1-2 folhas. Folhas bifaciais, conduplicadas, coriáceas, articuladas, verdes. Inflorescência lateral, tipo racemo, pendente, comprimento maior que as folhas, multiflora. Flores ressupinadas, pequenas, cremes, brancas, amarelas ou verdes, às vezes com marcas amarelas nas pétalas. Sépalas e pétalas similares; sépala dorsal livre; sépalas laterais parcialmente fundidas. Labelo inteiro, hastado, ecalcarado, base do labelo inserido perpendicularmente na base da coluna, base unguiculada, terete, ápice agudo, não emarginado; região do disco com calo simples, geralmente alongado, carenado. Coluna não alada, levemente reflexa; tábula infraestigmática ausente; clinândrio pouco desenvolvido, liso. Fruto cápsula elipsóide a suborbicular, não a levemente 3-angulada; frutos maduros com ápice dos carpelos unidos.

O gênero Notylia possui cerca de 60 espécies, distribuídas a partir do México, e na América Central, Panamá, Colômbia, Venezuela, Bolívia, Paraguai, Peru e Brasil (Chase 2009). No Brasil, ocorrem 25 espécies (15 endêmicas), nos biomas Amazônia, Cerrado e Mata Atlântica. No bioma Cerrado, ocorrem 10 espécies e para o Distrito Federal são citadas duas Notylia hemitricha Barb. Rodr. e Notylia lyrata S. Moore (Barros et al. 2015).

Notylia lyrata S. Moore. Trans. Linn. Soc. London, Bot. 4: 477, t. 32. 1895.

Figura $2 \mathrm{~g}$

Pseudobulbos 0,9-3 × 0,2-0,6 cm, verdes, protegidos lateralmente por bainhas foliosas, 3-8,1 cm, persistentes e articuladas, encimados por 1 folha. Folha 4,4-12 × 0,8-2,6 cm, séssil, elíptica a estreitamente obovada, bases atenuada, ápice obtuso. Inflorescência 5-20 cm compr., 10-90 ou mais flores. Flores pediceladas, pedicelos 3-5 $\mathrm{mm}$ comp. Sépalas similares, estreitamente elípticas a lineares, membranáceas, amarelas, bases atenuadas, margens inteiras, ápices agudos; sépala dorsal 4-5 × 0,6-1,5 mm; sépalas laterais 3-6,5 × 0,3-1 mm, 2/3 adnatas. Pétalas 3,5-6 × 0,7-1,1 mm, elípticas a lineares, membranáceas, amarelo-esbranquiçadas com duas pintas basais alaranjadas, bases atenuadas, margens inteiras, ápices agudos. Labelo 3-5 × 1,4-2,5 mm, brancoamarelado; base unguiculada 0,3-0,8 $\times 0,2-0,5 \mathrm{~mm}$, amarelada, ápice agudo a obtuso; lobo médio-apical 2,5-4 × 1,5-2,5 mm, oval-lanceolado, esbranquiçado; região do disco com calo carnoso, alongado, 
carenado. Coluna 1,5-2,5 × 0,3-1 mm, castanha. Fruto 8-9 $\times$ 4-5 mm, oblongo.

A espécie Notylia lyrata ocorre no Paraguai e Brasil (WCSP 2014). No Brasil, distribui-se no Distrito Federal e nos Estados do Amazonas, Bahia, Ceará, Espírito Santo, Goiás, Maranhão, Mato Grosso, Minas Gerais, Pará, Paraíba, Paraná, Pernambuco, Rio de Janeiro, Rio Grande do Sul, Santa Catarina, São Paulo e Tocantins (Barros et al. 2015). No Distrito Federal, vegeta em mata ciliar e mata de galeria, florescendo nos meses de junho a setembro, e frutificando nos meses de outubro a novembro.

Material selecionado: BRASIL. Distrito Federal: BR-020, Fazenda Rio Preto, 12-XI-1982, A.E. Ramos 166 (CEN). Caminho da FERCAL, próximo ao Rio Maranhão, 18-VIII-1979, L. Bianchetti 432 (HEPH). Fazenda Água Limpa, UnB, 22-VI-1988, Grupo da CRGF s.n. (CEN15122). IBGE, Córrego Roncador, 17VIII-1989, M.L.M. Azevedo 297 (IBGE). Núcleo Rural Jardim II, margem direita do Rio Preto, 16-X-2002, J.M. Rezende 630 (CEN). Parque Nacional de Brasília, Mata Córrego do Acampamento, 25-VI-2014, V.V. Queiroz 13 (UB). Santuário Ecológico do Riacho Fundo, X-1994, R.S. Oliveira 8 (UB).

Status de Conservação - Considerando os sete registros de herbário; considerando o fato de vegetar em Matas Ciliares e de Galeria (sujeitas a diversas situações de ameaça, como por exemplo: extração de madeira, desmatamentos para agricultura, remanescentes florestais fragmentados e expansão de área urbana); e por haver alguns registros em Áreas Protegidas de Preservação Integral e em Áreas Protegidas de Uso Sustentável (APA), no Distrito Federal, a espécie pode ser considerada como localmente vulnerável - VU A2c + B1ab (ii, iii).

Notylia hemitricha é citada para o Distrito Federal pela Lista de Espécies da Flora do Brasil (Barros et al. 2015). Os materiais testemunhos citados pela referida lista [A. Ghillany s.n. (HB68909); R.M. Klein \& A. Bresolin 8585 (FLOR;SC); C.N. Fraga 127 (MBML;ES)], não são do Distrito Federal. Como nenhum material que testemunhe a suposta ocorrência tenha sido localizado, acreditamos tratar-se de erro na identificação quando consideramos a similaridade morfológica, que de fato ocorre entre Notylia hemitricha e N. lyrata.

Plectrophora H. Focke. Tijdschr. Wis- Natuurk. Wetensch. Eerste K1. Kon. Ned. Inst. Wetensch.1: 212. 1848.

Ervas epífitas. Rizoma curto entre os caules secundários. Caules secundários intumescidos ou não em pseudobulbos, se presentes então reduzidos, ancipitados, encimados por 1 folha. Folha ensiforme, flabeliforme, unifacial, carnosa, lisa, articulada, verde. Inflorescência lateral, tipo racemo, comprimento menor que as folhas, geralmente uniflora. Flores ressupinadas, pouco vistosas, esverdeadas, brancas ou amarelas, às vezes com mancha fulvo-avermelhada no labelo. Sépalas dorsais livres, as laterais fundidas na base envolvendo o esporão nectarífero. Pétalas livres. Labelo inteiro a levemente bilobado, margens curvadas sobre a coluna, calcarado, base do labelo inserido perpendicularmente na base da coluna, base prolongada formando esporão protegido pelas sépalas laterais; região do disco ecaloso ou com par de cristas na base. Coluna não alada, fracamente arqueada; tábula infraestigmática ausente; clinândrio pouco desenvolvido, liso. Fruto cápsula elipsóide, 3-alada a fortemente 3-angulada; frutos maduros com ápice dos carpelos unidos.

O gênero Plectrophora possui cerca de nove espécies distribuídas na Costa Rica, Panamá, Venezuela, Colômbia, Equador, Peru, Bolívia e Brasil (Chase 2009). No Brasil, ocorrem cinco espécies (três endêmicas) nos biomas Amazônia e Cerrado. No bioma Cerrado, existem três espécies e no Distrito Federal ocorre uma espécie, Plectrophora edwallii Cogn. (Barros et al. 2015).

Plectrophora edwallii Cogn. F1. Bras. 3(6): 580. 1906.

Figura 2 c-d

Pseudobulbos ca. $9 \times 7 \mathrm{~mm}$, largo elípticos a suborbiculares, extremamente ancipitados, verdeamarelados, protegidos por bainhas $4,9-8 \mathrm{~cm}$, articuladas e persistentes. Folha 6,2-12,4 × 0,6-1,0 cm, elíptica a estreitamente oval, base truncada, ápice agudo. Inflorescência 4,9 cm comp., curta, com até 3 flores abrindo-se sucessivamente; Flores pediceladas, pedicelos 1,1-1,9 cm. Sépalas semelhantes, ovais, membranáceas, amarelo-pálidas, bases atenuadas, margens inteiras, ápices agudos; sépala dorsal ca. $10 \times 3 \mathrm{~mm}$; sépalas laterais $8-10 \times$ ca. $2 \mathrm{~mm}$. Pétalas ca. $11 \times 5 \mathrm{~mm}$, elípticas, membranáceas, amarelas, bases atenuadas, margens inteiras, ápices agudos. Labelo ca. $13 \times 8 \mathrm{~cm}$, obovado, margem erosa, ápice obtuso, amarelo com estrias mais escuras acompanhando as nervuras; esporão ca. $9 \times 1-2 \mathrm{~mm}$. Coluna ca. $3 \times 1 \mathrm{~mm}$. Fruto ca. $2 \times 1,5 \mathrm{~cm}$, elipsóide.

A espécie Plectrophora edwallii ocorre na Bolívia, Peru e Brasil (Tropicos 2014). No Brasil, 
distribui-se no Distrito Federal e nos Estados do Goiás, Mato Grosso, Minas Gerais e Pará (Barros et al. 2015). No Distrito Federal, vegeta em mata ciliar sobre afloramento calcário, mata mesofítica semidecídua, e floresce nos meses de abril e agosto, frutificando no mês de abril.

Material examinado: BRASIL. Distrito Federal: FERCAL, entradada grutadaPedraEncantada,20-IV-2006, J.M. Rezende 1071 (CEN). Margens do Rio Preto, Divisa do DF com MG, 5-VIII-1963, E.P. Heringer 9186 (UB).

Status de Conservação - Considerando os quatro registros de herbário; considerando o fato de vegetar em Matas Ciliares sobre afloramento calcário e Matas Mesofíticas (sujeitas a diversas situações de ameaça, como por exemplo: extração mineral, extração de madeira, desmatamentos para agricultura, remanescentes florestais fragmentados e expansão de área urbana); e por não haver registros em Áreas Protegidas de Preservação Integral e apenas em Áreas Protegidas de Uso Sustentável (APA), no Distrito Federal, a espécie pode ser considerada como localmente em perigo - EN B1ab (ii, iii).

Rodriguezia Ruiz \& Pav. Fl. Peruv. Prodr. 115, t. 25. 1794.

Ervas epífitas. Rizoma curto a extremamente longo entre os caules secundários. Caules secundários intumescidos em pseudobulbos, alongados a orbiculados, encimados por 1-4 folhas. Folhas bifaciais, conduplicadas, coriáceas, articuladas, verdes. Inflorescência lateral, geralmente tipo racemo, geralmente maior que as folhas, pauci- a multiflora. Flores ressupinadas, vistosas, amarelas, rosas ou carmins, muitas vezes com marcas vermelhas e amarelas nas sépalas e labelo. Sépala dorsal livre; base das sépalas laterais fundidas envolvendo o mento nectarífero. Pétalas livres. Labelo inteiro, oblanceolado, base do labelo inserido perpendicularmente na base da coluna, base prolongada formando pequeno mento ou não, ápice dilatado, geralmente emarginado; região do disco com uma ou mais carenas ou cristas. Coluna com par de braços desenvolvidos no ápice e par de braços menores ladeando o estigma, base levemente projetada secretando néctar dentro do mento, tábula infraestigmática ausente, clinândrio pouco desenvolvido, liso. Fruto cápsula elíptica a ovóide, não a levemente 3 -angulada; frutos maduros com ápice dos carpelos unidos.

O gênero Rodriguezia possui cerca de 50 espécies distribuídas a partir do México, América Central,
Colômbia, Venezuela, Argentina, Bolívia, Peru e Brasil (Chase 2009). No Brasil, ocorrem 22 espécies (17 endêmicas) nos biomas Amazônia, Cerrado e Mata Atlântica. No bioma Cerrado ocorrem quatro espécies e no Distrito Federal ocorre uma espécie, Rodriguezia decora (Lem.) Rchb. f. (Barros et al. 2015).

Rodriguezia brachystachys também é citada para o Distrito Federal (Barros et al. 2015), mas não foi encontrado nenhum material para a região e foi retirada da atualização.

Rodriguezia decora Rchb. f.,Bot. Zeitung (Berlin) 10: 771.1852.

Figura 3 a-c

Rizoma 3-19,5 cm, longo entre os pseudobulbos. Pseudobulbos 1-2,5 × 0,4-1,7 cm, elípticos a obovados, castanho-esverdeados, protegidos lateralmente por bainhas foliares $4,2-12,7 \mathrm{~cm}$, articuladas e persistentes, encimados por 1 folha. Folha 2,9-13 × 0,7-2,3 cm, séssil, estreitamente ovalada a elíptica, base atenuada, ápice agudo, rotundo a mucronado. Inflorescência 12-29 cm comp., 5-15 ou mais flores. Flores pediceladas, pedicelos $0,8-1,1 \mathrm{~cm}$ comp. Sépalas similares, elípticas, membranáceas, brancas ou levemente róseas pintalgadas de vinho, bases atenuadas, margens inteiras, ápices agudos; sépala dorsal $0,8-1,7 \times 0,3-0,5 \mathrm{~cm}$, sépalas laterais 1,3-1,9 $\times 0,1-0,3 \mathrm{~cm}, 2 / 3$ adnatas, encobrindo pequeno mento na base do labelo. Pétalas 1,3-1,8 $\times 0,3-0,8 \mathrm{~cm}$, ovaladas, membranáceas, brancas pintalgadas de vinho com leve coloração rósea no centro, bases atenuadas, margens inteiras, ápices obtusos. Labelo 1,6-3 × 1-1,9 cm, base atenuada, unguiculada, presença de pequeno mento, parte mediana pintalgada de vinho, parte apical dilatada, rotundado-reniforme, ápice emarginado, branca sem pintas; região do disco 2-lamelado, serreado. Coluna 4-7 × ca. $1 \mathrm{~mm}$, castanho-escura, braços apicais 4 , ligulados, braços posteriores menores, 1-2 mm comp., braços anteriores maiores, 3-4 mm comp. Fruto não visto.

A espécie Rodriguezia decora ocorre no Paraguai, Argentina e Brasil (WCSP 2014). No Brasil, distribui-se no Distrito Federal e nos Estados do Paraná, Rio Grande do Sul, Santa Catarina e São Paulo (Barros et al. 2015). No Distrito Federal, vegeta em ambientes de mata de galeria e mata inundada, florescendo entre dezembro a março.

Material selecionado: BRASIL. Distrito Federal: Colégio Agrícola, 23-XII-2003, A.E.H. Salles 2899 (HEPH). Fazenda Sucupira, Mata do Riacho Fundo, 
7-III-2000, J.A.N. Batista 1052 (CEN). Mata entre o Guará e o Setor de Indústria, 21-II-1981, F. Chagas 369 (IBGE). Parque Nacional de Brasília, Córrego do Acampamento, 4-III-1983, A.E. Ramos 234 (CEN, HEPH). Parque Zoobotânico, 6-III-1961, E.P. Heringer 8063 (UB). Reserva Ecológica do Guará, 2-II-2001, Z.J.G. Miranda 71 (CEN). Reserva Ecológica do IBGE, Córrego Taquara, 17-III-1994, B.M.T. Walter 2089 (CEN).

Status de Conservação - Considerando os nove registros de herbário; considerando o fato de vegetar apenas em Matas de Galeria Inundáveis (sujeitas a diversas situações de ameaça, como por exemplo: extração de madeira, drenagem e desmatamento para agricultura e expansão de área urbana), e por haver boa parte dos registros em Áreas Protegidas de Preservação Integral, no Distrito Federal, a espécie pode ser considerada como localmente vulnerável VU A2c + B1ab (ii, iii).

Sanderella Kuntze. Rev. Gen. P1. 2: 649. 1891.

Ervas epífitas. Rizoma curto entre os caules secundários. Caules secundários intumescidos em pseudobulbos, elípticas, ancipitados, encimados por 1 folha. Folha conduplicada, bifacial, coriácea, articulada, verde ou arroxeada. Inflorescência lateral, tipo racemo, menor ou do mesmo comprimento das folhas, multiflora. Flores ressupinadas, pequenas e pouco vistosas, branco-esverdeadas com manchas castanho-avermelhadas. Sépala dorsal livre; sépalas laterais fundidas na maior parte. Pétalas livres. Labelo inteiro, oblongo a pandurado, ecalcarado, base do labelo inserido perpendicularmente na base da coluna, ápice não dilatado em relação à base, não emarginado; região do disco com calo elevado. Coluna alada, com pequenas projeções ladeando o estigma, ápice com discretos braços projetados para frente, tábula infraestigmática ausente, clinândrio pouco desenvolvido, liso. Fruto cápsula elipsóide, não a levemente 3-angulada; frutos maduros com ápice dos carpelos unidos.

O gênero Sanderella possui duas espécies distribuídas na Bolívia, Argentina e Brasil (Chase 2009). No Brasil, as espécies ocorrem nos biomas Cerrado e Mata Atlântica. No bioma Cerrado e Distrito Federal ocorre apenas Sanderella discolor (Barb. Rodr.) Cogn. (Barros et al. 2015).

Sanderella discolor (Barb. Rodr.) Cogn. in Mart., Fl. Bras. 3(6): 239, t. 50. 1905.

Pseudobulbos 5-12 × 1-5 mm, verdes, protegidos lateralmente por bainhas $0,6-2,7 \mathrm{~cm}$, paleáceas, persistentes. Folha 2,4-7,7 × 0,3-1 cm, séssil, elíptica a lanceolada, base atenuada, ápice agudo, verdeescura. Inflorescência 1,5-8 cm comp., 5-19 flores. Flores pediceladas, pedicelos 1-4 mm compr. Sépalas similares, levemente obovadas, membranáceas, esbranquiçadas com as bases vináceas, bases estreitadas, margens inteiras, ápices agudos; sépala dorsal 2-3 × 1-2 $\mathrm{mm}$; sépalas laterais 2-3 $\times 1-2 \mathrm{~mm}, 2 / 3$ adnatas. Pétalas $2-3 \times$ ca. $1 \mathrm{~mm}$, obovadas, membranáceas, esbranquiçadas, bases truncadas, margens inteiras, ápices agudos. Labelo 2-3 × 0,6-1 mm, pandurado, ápice obtuso, reflexo, levemente acuminado; região do disco com calo bilamelado. Coluna 1-1,5 × 0,3-0,7 mm, castanha. Fruto não visto.

A espécie Sanderella discolor ocorre na Argentina, Bolívia e Brasil (Tropicos 2014). No Brasil, distribui-se no Distrito Federal e nos Estados do Goiás, Minas Gerais, Paraná, Rio Grande do Sul e São Paulo (Barros et al. 2015). No Distrito Federal, ocorre em mata de galeria e mata de galeria inundável, e floresce nos meses de maio e junho.

Material selecionado: BRASIL. Distrito Federal: Córrego Acampamento, 23-V-1991, J.A.N. Batista 199 (CEN). Fazenda Sucupira, 8-VI-1995, M.C. Assis 230 (CEN). Margem do Riacho Fundo, Fundação Zoobotânica, s.d., E.P. Heringer s.n. (UB8333). Sobradinho dos Melos, 25-VI-2005, A.H. Salles 3787 (HEPH).

Status de Conservação - Considerando os seis registros de herbário; considerando o fato de vegetar apenas em Matas Ciliares e Matas de Galeria Inundáveis (sujeitas a diversas situações de ameaça, como por exemplo: extração de madeira, drenagem e desmatamento para agricultura e expansão de área urbana), e por haver parte dos registros em Áreas Protegidas de Preservação Integral, no Distrito Federal, a espécie pode ser considerada como localmente vulnerável VU A2c + B1 ab (ii, iii).

Trichocentrum Poepp. \& Endl. Nov. Gen. Sp. P1. 2: 11, pl. 115. 1836. stricto sensu

Ervas epífitas. Rizoma curto entre os caules secundários. Caules secundários intumescidos em pequenos pseudobulbos, ovóides a cilíndricos, encimados por 1 folha. Folha conduplicada, bifacial, carnosa, articulada, verde, geralmente pintalgadas de roxo. Inflorescência lateral, tipo racemo ou panícula, comprimento menor que as folhas, pauciflora. Flores ressupinadas, vistosas, de coloração combinada de 
castanho, rosa, roxo, amarelo e branco. Sépalas e pétalas livres e similares entre si. Labelo inteiro a trilobado, calcarado, base do labelo inserido perpendicularmente na base da coluna, lobo apical bilobado, margens inteiras; região do disco com calo tuberculoso ou com carenas ou lâminas longitudinais. Coluna não alada, aurículas ou braços apicais desenvolvidos, petalóides, tábula infraestigmática ausente, clinândrio pouco desenvolvido, liso. Fruto cápsula elipsóide, geralmente não 3-angulada, ocasionalmente alada; frutos maduros com ápice dos carpelos unidos.

O gênero Trichocentrum possui cerca de 30 espécies distribuídas em toda a região neotropical, desde o sul da Flórida, México, América Central, Caribe, Argentina, Uruguai, Paraguai, Peru e Brasil (Chase 2009). No Brasil, ocorrem cinco espécies (duas endêmicas) nos biomas Amazônia, Cerrado e Mata Atlântica. No Cerrado, ocorrem duas espécies e no Distrito Federal ocorre apenas Trichocentrum albococcineum Linden (Barros et al. 2015).

Trichocentrum albococcineum Linden. Belgique Hort. 15: 103. 1865.

Figura $3 \mathrm{~g}-\mathrm{h}$

Pseudobulbos $0,5-0,7 \times 0,2-0,4 \mathrm{~cm}$, verdes. Folha 6,4-13,6 × 1,2-1,8 cm, séssil, elíptica a ovada, base atenuada, ápice agudo. Inflorescência 4-4,5 cm compr., tipo racemo, 1-2 flores. Flores pediceladas, pedicelos 3-4 cm comp. Sépalas obovadas, membranáceas, verde-acastanhadas, base levemente estreitada, ápice agudo-acuminado; sépala dorsal ca. 1,9 × 0,9 cm; sépalas laterais 1,9-2,2 × 0,5-0,7 cm. Pétalas ápice obtuso, 1,8-1,9 × 0,7-0,9 cm. Labelo pandurado, branco com duas faixas laterais coccíneas, 2,8-3,4 ×2-2,2 cm; base estreitada, ca. $9 \mathrm{~mm}$ comp., ápice emarginado, esporão 6-8 mm compr.; região do disco com calo lamelado. Coluna ca. 0,7 ×0,4 cm, castanho-escura. Fruto não visto.

A espécie Trichocentrum albococcineum ocorre na Bolívia, Peru e Brasil (Tropicos 2014). No Brasil, distribui-se no Distrito Federal e nos Estados do Amazonas, Goiás, Mato Grosso, Mato Grosso do Sul, Pará e Rondônia (Barros et al. 2015). No Distrito Federal, vegeta em matas de galeria e floresce em fevereiro.

Material examinado: BRASIL. Distrito Federal: Estação Ecológica de Águas Emendadas, 12-II-2014, J.H. Lima 55 (UB).
Material adicional examinado: BRASIL. GoiÁs: Catalão, Fazenda Barra a $3 \mathrm{~km}$ de Davinopolis, s.d., A.H. Salles et al. 2658 (HEPH).

Status de Conservação - Considerando apenas um registro de herbário; considerando o fato de vegetar apenas em Matas de Galeria (sujeitas a diversas situações de ameaça, como por exemplo: extração de madeira, desmatamentos para agricultura, remanescentes florestais fragmentados e expansão de área urbana) e por haver o único registro em Áreas Protegidas de Preservação Integral, no Distrito Federal, a espécie pode ser considerada como localmente criticamente em perigo - CR B lab (ii, iii).

Trichopilia Lind1., Edwards's Bot. Reg. 22: t. 1863. 1836.

Ervas epífitas. Rizoma curto entre os caules secundários. Caules secundários intumescidos em pseudobulbos, teretes a lateralmente ancipitados, encimados por 1 folha. Folha conduplicada, bifacial, carnosa a coriácea, articulada, verde. Inflorescência lateral, tipo racemo, geralmente mais curta que as folhas, pauciflora. Flores ressupinadas, pequenas, geralmente brancas com pintas róseas. Sépalas e pétalas livres e similares entre si. Labelo inteiro, ecalcarado, base do labelo inserido perpendicularmente na base da coluna, margens basais curvadas sobre a coluna; região do disco com carenas próximas à base, às vezes papilosas. Coluna metade do comprimento do labelo, reta; tábula infraestigmática ausente; clinândrio muito desenvolvido (comprimento acima da antera), lacerado. Fruto cápsula elíptica a ovóide, não a levemente 3-angulada; frutos maduros com ápice dos carpelos unidos.

O gênero Trichopilia possui cerca de 26 espécies distribuídas desde o México, América Central e Venezuela, Colômbia, Equador, Bolívia, Peru e Brasil (Chase 2009). No Brasil, ocorrem cinco espécies (duas endêmicas) nos biomas Amazônia, Cerrado e Mata Atlântica (Barros et al. 2015). No Distrito Federal, ocorre apenas uma espécie, Trichopilia brasiliensis Cogn., até então não citada e registrada pela primeira vez no presente estudo.

Trichopilia brasiliensis Cogn. in Mart., F1. Bras. 3(6): 580. 1906.

Figura $3 \mathrm{~d}$

Pseudobulbos 1,8-2,4 × 0,2-0,3 cm, teretes a subcilíndricos, verdes, protegidos por bainhas paleáceas, persistentes. Folha 16-18 × 0,7-0,8 cm, 
séssil, estreitamente elíptica a linear, base truncada, ápice agudo, coriácea. Inflorescência 3-6 cm compr., 1-5 flores. Flores pediceladas, pedicelo 0,9-1,1 cm compr. Sépalas e pétalas elípticas, membranáceas, creme-esverdeadas com pequenas pintas arroxeadas, base estreitada, ápice acuminado; sépala dorsal 1,5-1,6 × 0,3-0,4 cm, sépalas laterais $1,6-1,8 \times 0,2-0,3 \mathrm{~cm}$; pétalas $1,4-1,5 \times$ ca. $0,4 \mathrm{~cm}$. Labelo 1,2-1,3 × 1-1,1 cm, largo-elíptico, côncavo, base com duas protuberâncias ladeando a coluna, ápice agudo, creme com maior quantidade de pintas roxas que nas sépalas e pétalas e algumas vezes com carenas longitudinais escuras. Coluna 4-5 mm compr., castanha. Fruto não visto.

A espécie Trichopilia brasiliensis ocorre exclusivamente no Brasil. Distribui-se pelo Distrito Federal e pelos Estados do Espírito Santo, Goiás, Maranhão, Mato Grosso, Pará e Rondônia (Barros et al. 2015). No Distrito Federal, vegeta em mata ciliar e floresce em janeiro.

Material examinado: BRASIL. Distrito Federal: DF-100, Sentido Formosa, Fazenda Manga, $15^{\circ} 57^{\prime} \mathrm{S}$, 4722'O, 31-I-2007, A.A. Santos 1769 (CEN).

Material adicional examinado: BRASIL. GoIÁs: Pirenópolis, Santuário Ecológico do Vaga Fogo, 28-II-1992, L. Bianchetti 1238 (CEN).

Status de Conservação - Considerando apenas um registro de herbário; considerando o fato de vegetar apenas em Matas de Galeria (sujeitas a diversas situações de ameaça, como por exemplo: extração de madeira, desmatamentos para agricultura, remanescentes florestais fragmentados e expansão de área urbana) e por não haver nenhum registro em Áreas Protegidas de Preservação Integral, no Distrito Federal, a espécie pode ser considerada como localmente criticamente em perigo - CR B1ab (ii, iii).

\section{Agradecimentos}

Ao apoio do Projeto Protax/CNPq (Processo 562340/2010-6).

\section{Literatura citada}

Aguiar, J.M.R.B.V. 2014. Biologia reprodutiva das Ionopsis Kunth (Orchidaceae) do Brasil. Tese de Mestrado, Universidade de São Paulo, Ribeirão Preto.

Baptista, D.H., Harding, P.A. \& Neto, A.D. 2011. Orchids of Brazil: Oncidiinae I. Associação Orquidófila Piracicabana. 1 ed. Piracicaba, Piracicaba, São Paulo, Brasil. pp. 21-29.
Barros, F. de, Vinhos, F., Rodrigues, V.T., Barberena, F.F.V.A., Fraga, C.N., Pessoa, E.M., Forster, W., Menini Neto, L., Furtado, S.G., Nardy, C., Azevedo, C.O. \& Guimarães, L.R.S. 2015. Orchidaceae. In: Lista de Espécies da Flora do Brasil. Jardim Botânico do Rio de Janeiro. Disponível em http://floradobrasil.jbrj.gov. br/jabot/floradobrasil/FB19976 (acesso em 24-I-2015).

Batista, J.A.N. \& Bianchetti, L.B. 2003. Lista atualizada das Orchidaceae do Distrito Federal, Brasil. Acta Botanica Brasilica 17: 183-201.

Batista, J.A.N., Bianchetti, L.B. \& Pellizzaro, K.F. 2005. Orchidaceae Reserva Ecológica do Guará, Distrito Federal, Brasil. Acta Botanica Brasilica 19: 221-232.

Bianchetti, L.B., Batista, J.A.N., Pellizzaro, K.F. \& Augusto, M.M. 2005. Família Orchidaceae na APA de Cafuringa. In: P. Braga Netto, V.V. Mecenas, E.S. Cardoso (eds.). APA de Cafuringa: a última fronteira natural do DF. Secretaria de Meio Ambiente e Recursos Hídricos Semarh, Brasília, pp. 153-163.

Braem, G.J. 1993. Studies in the Oncidiinae - discussion of some taxonomic problems with description of Gudrunia Braem, gen. nov. and reinstatement of the genus Lophiaris Rafinesque. Schlechteriana 4: 17-21.

Carnevali, G., Cetzal-Ix., Balam, R., Leopardi, C. \& Romero-Gonzalez, G.A. 2013. A combined evidence phylogenetic re-circumscription and a taxonomic revision of Lophiarella (Orchidaceae: Oncidiinae). Systematic Botany 38: 46-63.

Cavalcanti, T.B. \& Ramos, A.E. 2001. O Projeto "Flora do Distrito Federal, Brasil". In: T.B. Cavalcanti \& A.E. Ramos (orgs.). Flora do Distrito Federal, Brasil. Embrapa Recursos Genéticos e Biotecnologia EMBRAPA CENARGEN, Brasília, pp. 13-44.

Cetzal Ix, W.R.C., Fernández-Concha, G.C. \& Castro, V.P. 2012. Cohniella (Orchidaceae: Oncidiinae) South of the Amazon River. Systematic Botany 37: 58-77.

Chase, M.W. 2009. Subtribe Oncidiinae. In: A.M. Pridgeon, P.J. Cribb, M.W. Chase \& F.N. Rasmussen. Genera Orchidacearum. Epidendroideae (Part Two). Oxford University Press, Oxford v. 5, pp. 211-391.

Chase, M.W., Williams, N.H., Faria, A.D., Neubig, K.M., Amaral, M.C.E. \& Whitten, M.W. 2009. Floral convergence in Oncidiinae (Cymbidieae: Orchidaceae): an expanded concept of Gomesa and a new genus Nohawilliamsia. Annals of Botany 104: 387-402.

Codeplan. 1984. Atlas do Distrito Federal II. Governo do Distrito Federal, Brasília.

CRIA. 2005. Flora brasiliensis - a obra. Disponível em http://florabrasiliensis.cria.org.br (acesso em 02-I-2015).

Docha Neto, A. \& Benelli, A.P. 2006. Alatiglossum culuenense: uma nova espécie de Orchidaceae de Mato Grosso, Brasil. Orchidstudium 5: 55-77. 
Cribb, P.J. 2009. Tribe Cymbidieae. In: A.M. Pridgeon, P.J. Cribb, M.W. Chase \& F.N. Rasmussen. Genera Orchidacearum. Epidendroideae (Part Two). Oxford University Press, Oxford, v. 5. pp. 3-9.

Dodson C.H. 2003. Native Ecuadorian Orchids. v. 5. The Dodson Trust: Sarasota.

Dressler, R.L. 1981. The Orchids: Natural History and Classification. Harvard University Press, Cambridge.

Françoso, R.D., Brandão, R., Nogueira, C.C., Salmona, Y.B., Machado, R.B., Colli, G.R. 2015. Habitat loss and the effectiveness of protected areas in the Cerrado Biodiversity Hotspot. Natureza \& Conservação 13: 35-40.

Garay, L.A. \& Stacy, J.E. 1974. Synopsis of the Genus Oncidium. Bradea 40: 393-424.

INCT - Herbário Virtual da Flora e dos Fungos. 2014. Disponível em http://inct.florabrasil.net/ (acesso em 15-XII-2014).

Jiménez-Machorro, R. \& Carnevali, G. 2001. Nomenclatural notes: new combinations in Lophiaris Raf. (Orchidaceae). Harvard Papers in Botany 6: 283-284.

Königer, W. \& Pongratz, D. 1997. Stilifolium: a new name for the section Cebolletae of the genus Oncidium as a new genus in subtribe Oncidiinae. Arcula 7: 186-190.

Königer, W. \& Pongratz, D. 1999. Intended combination not made: Oncidium sprucei. Arcula 9: 265.

Lista de Espécies da Flora do Brasil. Jardim Botânico do Rio de Janeiro. Disponível em http://floradobrasil.jbrj. gov.br/ (acesso em 24-II-2015).

Maury, C. M., Ramos, A. E. \& Oliveira, P. E. 1994. Levantamento florístico da estação ecológica de Águas Emendadas. Boletim do Herbário Ezechias Paulo Heringer 1: 46-67.

Meneguzzo, T.E.C., Bianchetti, L.B. \& Proença, C.E.B. 2012. O gênero Encyclia (Orchidaceae) no Distrito Federal, Goiás e Tocantins. Rodriguésia 63: 277-292.

Nogueira, P.E., Nóbrega, M.G.G. \& Pereira da Silva, G. 2002. Levantamento florístico e fisionomias do Parque Ecológico Ezechias Heringer (Parque do Guará) Distrito Federal, Brasil. Boletim do Herbário Ezechias Paulo Heringer 10: 31-56.

Pellizzaro, K.F., Batista, J.A.N. \& Bianchetti, L.B. 2004. O gênero Oncidium Benth. (Orchidaceae) no Distrito Federal, Brasil. Boletim do Herbário Ezechias Paulo Heringer 14: 128-143.

Penha, T.L.L., Corrêa, A.M. \& Catharino, E.L.M. 2011. Números cromossômicos em Kleberiella V.P. Castro \& Cath. (Orchidaceae, Oncidiinae) e gêneros afins. Acta Botanica Brasilica 25: 466-475.

Pereira, B.A.S., Silva, M.A. \& Mendonça, R.C. 1993. Reserva Ecológica do IBGE, Brasília (DF): lista das plantas vasculares. IBGE, Rio de Janeiro.

Proença, C.E.B., Munhoz, C.B.R., Jorge, C.L. \& Nóbrega, M.G.G. 2001. Listagem e nível de proteção das espécies de fanerógamas do Distrito Federal, Brasil. In: T.B. Cavalcanti \& A.E. Ramos (orgs.). Flora do Distrito Federal, Brasil. Embrapa Recursos Genéticos e Biotecnologia EMBRAPA CENARGEN, Brasília, pp. 89-359.
Pupulin, F. 1995. A revision of the genus Trichocentrum (Orchidaceae: Oncidiinae). Lindleyana 10: 183-210.

Pupulin, F. \& Carnevali, G. 2005. Cohniella Pfitz. In: F. Pupulin (ed.). Vanishing Beauty: Native Costa Rican Orchids. Costa Rica University Press, San José, v. I, pp. 141-147.

Ribeiro, J.F. \& Walter, B.M.T. 1998. Fitofisionomias do bioma Cerrado. In: S.M. Sano \& S.P. Almeida (eds.). Cerrado: ambiente e flora. EMBRAPA-CPAC, Planaltina, pp. 89-166.

Rodrigues, V.T. 2011. Orchidaceae Juss. Aspectos morfológicos e taxonômicos. Instituto de Botânica, São Paulo.

Sandoval-Zapotitla, E. \& Terrazas, T. 2001. Leaf anatomy of 16 taxa of the Trichocentrum clade (Orchidaceae: Oncidiinae). Lindleyana 16: 81-93.

Sarmiento, J. 2007. La familia Orchidaceae en Colombia, Actualidades biológicas, 29: 21-84.

Silva, D. G. 1999. O gênero Oncidium Benth. (Orchidaceae) na chapada Diamantina, Bahia, Brasil. Tese de Mestrado, Universidade Estadual de Feira de Santana, Feira de Santana.

Sloan, S., Jenkins, C.N., Joppa, L.N., Gaveau, D.L.A. \& Laurance, W.F. 2014. Remaining natural vegetation in the global biodiversity hotspots. Biological Conservation 177: 12-24.

Sosa, V., Chase, M.W., Salazar, G.E., Whitten, W.M. \& Williams, N.H. 2001. Phylogenetic position of Dignathe (Orchidaceae: Oncidiinae): evidence from nuclear ITS ribosomal DNA sequences. Lindleyana 16: 94-101.

Thiers, B.M. 2015. Index Herbariorum: A global directory of public herbaria and associate staff. New York Botanical Garden's Virtual Herbarium. Disponível em http://sweetgum.nybg.org/ih/ (acesso em 22-VI-2015).

Tropicos. 2014. Missouri Botanical Garden. Disponível em http://www.tropicos.org/ (acesso em 10-XII-2014).

Walter, B.M.T. \& Sampaio, A.B. 1998. A vegetação da fazenda Sucupira. Embrapa Recursos Genéticos e Biotecnologia, Brasília.

WCSP. 2014. World Checklist of Selected Plant Families. Facilitated by the Royal Botanic Gardens, Kew. Published on the Internet. Disponível em http://apps. kew.org/wcsp/ (acesso em 1-VI-2014).

Williams, N.H. 1974. Taxonomy of the genus Aspasia Lindley (Orchidaceae: Oncidieae). Brittonia 26: 333-346.

Williams, N.H., Chase, M.W., Fulcher, T. \& Whitten, W.M. 2001. Molecular systematics of the Oncidiinae based on evidence from four DNA sequence regions: expanded circumscriptions of Cyrtochilum, Erycina, Otoglossum and Trichocentrum and a new genus (Orchidaceae). Lindleyana 16: 113-139. 